\title{
Elazığ Müzesindeki Osmanlı Dönemi Eşik ve Seccade Halıları
}

\section{The Threshold and Prayer Carpets Belonging to the}

İsmail AYTAÇ*

Ottoman Period in Elazig Museum

\section{ÖZET}

Bu bildiride ele alınacak eşik ve seccade ha-

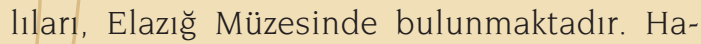
lıların incelenmesinde, envanter numarası, müzeye geliş tarihi ve kimden satın alındığı, ebatları, hav yükseklikleri, düğüm sayıları, motif ve kompozisyon özellikleri belirtilmiştir. Halıların motifleri çizilmiş ve fotoğrafları çekilmiştir.

Müzede incelenen sedir halıların atkı, çözgü ve düğüm ipliklerinde genellikle yün malzeme kullanılmıştır. İncelenen halılarda, ipliklerin boyanmasında çoğunlukla doğal, az olarak suni boyalar kullanılmıştır. Atkı ve çözgüler genellikle boyanmamıştır. İncelenen 5 adet halıda Türk (Gördes) düğüm tekniği kullanılmiştır.

Halıların bir kısmı Elazığ ve yöresinde dokunmuş, diğer kısmı da bölgeye satılarak getirilmiştir. Şavak halıları olarak bilinen örnekler, yöreye has renk ve motif özellikleri taşımaktadır. İncelenen halılar 18. yüzyılın sonları ile 20. yüzyılın başlarında dokunmuştur.

Anahtar Kelimeler: Osmanlı Halısı, Halı, Seccade, Motif, Elazığ Müzesi.

\section{Giris}

\subsection{Elazığ’ın Tarihi Coğrafyası}

Elazı ̆̆ İli, Doğu Anadolu bölgesinin güneybatısında yukarı, Firat bölümünde yer almaktadır'. $40^{\circ} 21^{\prime}$

* Doç. Dr., Fırat Üniversitesi Eğitim Fakültesi Öğretim Üyesi / ELAZIĞ iaytac@firat.edu.tr

11998 Yilı Elazığ Ill Yillığı, Elazı ğ Valiliğ̈i, Ankara 1998, s. 19

\section{ABSTRACT}

In this report, the threshold and prayer rugs to be tacled are availabel in Elazığ Museum. When the rugs were studied, their inventory numbers, bringing dates to the museum, who or whom they were bought from, their dimensions, pile heights, number of nodes, features of design and composition have been defined. The motifs of rugs have been drawn and their pictures were taken.

Woolen materials were used in warp yarns and the nodes of the weft of the cedar carpets that were sturdied in the museum. Mainly natural dye and sometimes very little of the synthetic dye was used in yarn dyeing of the carpets. Wefts and warps weren't dyed generally. The Turkish (Gördes) knot technique was used in five carpets studied.

Some of the carpets were weaved in and around Elazı $\breve{g}$ and the others were bought from the other parts of the country by purchasing. The examples called as the Şavak carpets represent the motfis caracteristics of the area's colors. The carpets studied belong to end of the $18^{\text {th }}$ and beginning of the $20^{\text {th }}$ centuries.

Key Words: Carpets of Ottoman, Carpet, Prayer Carpet, Motif, Elazığ Museum.

ile 38 $30^{\prime}$ doğu boylamları, $38^{\circ} 17^{\prime}$ ile $39^{\circ} 17^{\prime}$ kuzey enlemleri arasında kalmaktadır. i̇li doğudan Bingöl, kuzeyden Keban Baraj gölü aracılığı ile Tunceli, batı ve güney-batıdan Karakaya Baraj gölü vasıtasıyla Malatya, güneyden ise Diyarbakır illerinin arazileri çevrelemektedir. 
Doğu Anadolu Bölgesi, yükselti bakımından Anadolu'nun önemli bir konumunu teşkil eder. Doğu-batı doğrultusunda uzanan Güneydoğu Toroslar, Elazı̆̆ ilini güneyden bir sur gibi çevreleyerek doğuya doğru uzanırlar

Harput yöresinin tarih olarak adı bilinen en eski sakinleri Hurriler ve bu kavmin kurduğu Mitanni Devletidir ${ }^{3}$ Devaminda Hititler, Asurlular, Urartu, İran, İskender, Roma, Bizans hâkimiyetlerinden sonra VII. Yüzyılda Arapların iskanı görülmektedir. 938 yılında da Arapların elinde bulunduğ $\mathrm{u}^{4}$, 987-989 yıllarındaki isyanlar esnasında buradaki Bizans hâkimiyetinin büyük ölçüde çöktüğü ifade edilmektedir ${ }^{5}$. Bu bölge "El-Cezire Ucu" olarak adlandirılmaktaydı. Bu alanın en belirgin şehirleri arasında Hısn-Ziyad (Harput), Şimşat (Arsamat) diye anılan bugünkü Haraba yer alıyordu. Bu yöreler sınır bölgesi olduğu için özellikle Türklerin yerleştirildiği, IX. Yüzyılından itibaren Horasan ve Türkistan'dan getirilen gazilerin iskan edildiği belirtilmektedir ${ }^{6}$. Doğu Anadolu'ya başlayan Türk akınları 1047 yılından itibaren sıklaşmıştır. Harput'a ilk Türkmen akını 1058 sonrasında Yakuti komutasında yapılmıştır?.

Sultan Alp Arslan Malazgirt zaferini müteakip maiyeti erkanına bölgeleri taksim etmiş, Emir Artuk Bey'e Mardin, Amid, Malatya, Harput ve civar1nı ikta ederek buraların fethedilmesini emretmiştir ${ }^{8}$. X. Yüzyıl ortalarında Bizanslıların geri aldığı bölge 1071'den sonra Çubuk Bey tarafından fethedilmiştir? Şehir 1110’larda Artukluların (Belek) eline geçmiştir $^{10}$. Harput'ta ilk Artuklu beyliğini tesis eden Belek Özellikle Haçlılara karşı parlak zaferler kazanan gazilerden birisidir ${ }^{11}$. XII. Yüzyıl başlarında başlayan bu dönem 1234 yılına kadar sürmüştür ${ }^{12}$

1234'te Anadolu Selçuklu topraklarına katılan şehir ${ }^{13}$ Selçuklu Sultanı Gryaseddin Keyhüsrev II, 1243 Kösedağ Savaşında Moğallara yenilmesinden sonra İlhanlılara bırakılmak zorunda kalınmıştır ${ }^{14}$. XIV.

2 S. Erinç, Doğu Anadolu Coğrafuası, İstanbul 1953, s.112; Ö. K. AĞAR, Tunceli Dersim Coğrafyası, İstanbul 1940, s. 8.

3 N. Ardıçoğlu, Harput Tarihi, Harput Turizm Derneği, İstanbul 1964, s. 6.

4 Ernst Honigmann, Bizans Devletinin Doğu Sınırı, (Tercüme eden: Fikret Iş1ltan), İstanbul 1970, s. 74

5 Ernst Honigmann, a.g.e., s. 148

6 M.H. Yinanç, Türkiye Tarihi Selçuklular Devri, İstanbul 1944, s. 26.

7 M.H. Yinanç, a.g.e., s. 56.

8 M.H. Yinanç, a.g.e., s. 80

9 O. Turan, Selçuklu Zamaninda Türkiye, İstanbul 1993, s. 112

10 O. Turan, a.g.e., s. 205-206.

11 M.H Yinanç, a.g.e, s. 125-126.

12 R. Ataoğlu, "Harput'ta Artuklu İdaresi", Tarih İçinde Harput, Elazı ̆ 1992, s. 53

13 O. Turan, a.g.e., s. 30

14 M. B. Aşan, Elazığ, Tunceli ve Bingöl Mllerinde Türk İskan İzleri, XII. Ve XIII Yüzyillar, Ankara 1992, s. 21
Yüzyıldan itibaren sırasıyla Dulkadiroğulları ${ }^{15}$, Kadı Burhaneddin $^{16}$, Karakoyunlu ${ }^{17}$, Akkoyunlu devletleri arasında el değiştirmiştir ${ }^{18}$. 1465'te Uzun Hasan şehri Akkoyunlu topraklarına katmıştır. XVI. yüzyıl başlarında Safeviler'in hakimiyetine girmiştir. 1516 yılında Çaldıran zaferinden sonra Osmanlı hâkimiyetine giren Harput ticaret yolunun üzerinde bulunuyordu ${ }^{19}$. Bu tarihten sonra ülkenin coğrafi konumu ve tarihi şartlarından dolayı önemli bir yerleşim merkezi olmuştur.

Evliya Çelebi Harput'ta 600'dan fazla dükkân bulunduğunu kaydediyor ${ }^{20}$. 1516'dan XIX. yüzyılın ortalarına kadar Diyarbakır eyaletine tabi bir sancak olarak kalmıştır. 1518 tarihli Tahrirde Harput'un 13 mahallesi bulunmaktadir ${ }^{21}$. Harput tarih boyunca daima önemli bir merkez teşkil etmesi sebebiyle burada birçok eser yapılmıştır. XVI. yüzyıl kayıtlarından sancak merkezi olan Harput'ta 22 vakıf bulunduğu öğrenilmektedir22.

Bugünkü Elazı̆̆g, XIX. Yüzyılda, tarihi Harput şehrinin yerini almıştır. Aynı adı taşıyan ovanın kuzey kenarında kuzeyden-güneye doğru alçalan hafif eğimli bir yüzey üzerine yayılır. XIX. Yüzyıl oltalarına da başlayarak Harput'ta yaşayan nüfus Elazığ'a inme eğilimini sürdürmüştür. Keban Baraj gölü altında kalan köylerin boşaltması nüfus yoğunluğunun artmasında etkili olmuştur ${ }^{23}$. Cumhuriyet döneminde "Elazık" olan adının söyleyiş zorluğundan ötürü 1937 tarihli İcra Vekilleri Heyetinin aldığı bir kararla bu adın Elazığ'a çevrilmiştir²4. Harput 1980 yılına kadar Bucak merkezi iken, bu yıldan sonra Elazı ğ Belediye sınırları içine alınmıştır.

\subsection{Elazığ Arkeoloji ve Etnografya Müzesi}

19. yüzyılın sonlarına doğru terk edilen Harput'ta tarihi eserlerin bir kısmının taşları sökülerek Elazı '̆’daki binaların yapımında kullanılmıştır. Uzun süre tahribata açık kalan eserlerin değeri 1960'lı yıllardan sonra anlaşılmış ve 1965 yılında Kayabaşındaki Alacalı Mescit "Harput Müzesi” olarak kurulmuştur. Toplanan

15 R. Yinanç, Dulkadirli Beyliği, Ankara 1987, s. 20

16 K. Y. Kopraman, Misır Memluklu Devleti, Ankara 1989, s. 173

17 F. Sümer, Karakoyunlular, I, Ankara 1984, s. 358.

18 B. Darkot, "Harput", I.A., C.5, s. 296-297.

19 M. B. Aşan, a.g.e., s. 26.

20 E. Çelebi, Seyehatname, C. 3-4, İstanbul 1986, s. 170-171.

21 M. F. Kırzıoğlu, "450 Yıl Önceki Harput Mahalleleri ile Nahiyeleri", Yeni Firat, S. 17, Kasım 1963, s. 17

22 Harput'taki eserler hakkında geniş bilgi için bkz. E. DANIK, “Ortaçağ Harput'tunun Kentsel Gelişimi”, Dün ve Bugünüyle Harput, Elazı ̆̆ 1999, s. 29; C. ARSLAN, Elazığ’da Türk İslam Dönemi Yapıları, Selçuk Üniversitesi, Sosyal Bilimler Ens. (Yayımlanmamış Doktora Tezi), Konya 2003.

23 M. Tuncel, Elazığ Maddesi, T.D.V. İ.A., İstanbul, 1994, C. 10, s. 553.

24 M. H. Yinanç, a.g.e., s. 229 
İsmail AYTAÇ

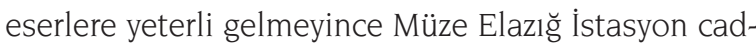
desindeki şimdiki tiyatro binasına taşınmıştır. Fırat Üniversitesi, Mühendislik kampüsündeki yeni müze binası 12.700 metrelik alan üzerine kurularak 1982 yılında sergi ve ziyarete açılmıştır. Modern mimarisi ve zengin eserleri ile Türkiye'deki sayılı örneklerden olan Elazığ Arkeoloji ve Etnografya Müzesi, arkeolojik eserler ve sikke salonu, halı-kilim ve Etnografya salonu olmak üzere üç salon ve depolardan oluşmaktadır ${ }^{25}$.

Halı-kilim salonunda yer, duvar, sedir, yastık halıları ile kilim ve cicimden yapılmış çuval, heybeler ser-

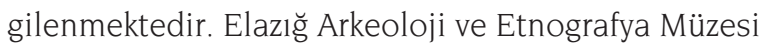
sergileme, araştırma, eser alma, değerlendirme ve ilim dünyasına sunma çabaları ile bir bölge müzesi olarak çalışmalarına devam etmektedir ${ }^{26}$.

\subsection{Halıların Tanımı ve Sınıflandırılması}

Halı, insanların örtü ve ihtiyaçlarını karşılamak için kullandıkları ilmeli dokumaların adıdır. Yüzü muhtelif renkli desenlerle süslü, bir nevi (havlı) ilmeli dokumalara halı adı verilir.

Türklerin anavatanı olan Orta Asya'da halı, keçe ve düz dokuma yaygılar (kilim, cicim, zili, sumak) yayg1 ve örtü malzemesiydi. Muhtemelen, önce bunların en ilkeli olan keçe keşfedilmiş, daha sonra halı geliştirilmiştir. Keçe, Orta Asya'da hem çadır dış ve iç örtüsü, hem yaygı, hem de bir süsleme malzemesiydi. Aynı gelenek günümüzde Anadolu'da da mevcuttur. Duvarlara halı, kilim asılır, saçaklar ve torbalarla süslenir. Orta Asya'da ev veya çadırın temel süsleme malzemesi, bugünkü anlamda mobilyası keçe ve halı idi. Yaylacılık yapan Türklerin kolayca taşıyabildikleri bu malzeme aynı zamanda evdeki refah seviyesinin de göstergesiydi. Bu gün Anadolu'da da, göçebe yaşayan vatandaşlar hâlâ, halıyı zenginlik. Kilim, cicim, zili gibi dokumaların orta halli, keçe, çul vb. dokumaların da fakirliği sembolize ettiğini kabul etmektedir. Yine, Orta Asya'da keçe yapımı için gerekli yün halkın kendi yetiştirdiği koyunlarından elde ediliyor, yünün sıkıştırılması veya toplanması ile de keçe yapılıyor$d^{27}$. Türkler XI. y.y'da keçeye kidhiz diyorlardı. Keçe, halı ve kilimden farklı bir şeydi. Kaşgarlı Mahmud'un yazdığı Divanü Lügati'-t - Türk'te açık bir şekilde birbirinden ayrılmakta, halı ve kilim kiwiz, kiviz şeklinde isimlendirilmekteydi ${ }^{28}$. Karahanlı sahası Türklerin ke-

25 G. Aytaç, "Elazı ̆̆ Arkeoloji ve Etnoğrafya Müzesi”, Harvak, Sayı: 2

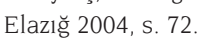

26 G. Aytaç, a.g.m., s. 72-74

27 Keçe hakkında detaylı bilgi için bkz. B. DENiz, “Türk Dünyasında Ölümlük Halı, Düz Dokuma Yaygı ve Keçe Geleneği”, Akdeniz Sanat Dergisi, Kasım 2009, Antalya 2009, s.1-16.

28 B. Deniz, Türk Dünyasında Halı ve Düz Dokuma Yaygıları, AKM Yayınları, Ankara 2000, s.6 çeye kiviz demelerine karşılık, Oğuzboyları XI.y.y.da keçe kelimesini kullanmaktaydi ${ }^{29}$. Türklerde keçeciliğin çok ileri bir düzeyde bulunduğunu Pazırk kurganlarında ortaya çıkan ve günümüze kadar gelebilen örneklerinden anliyoruz ${ }^{30}$.

Kaynaklar, Kaşgarlı Mahmud'un XI. yy.da yazdığı Divanü Lüğati-t-Türk'te halı, kilim, keçe, döşek gibi yere serilen eşyalara kıviz, kiwiz, küvüz, tüllüğ yazım denildiğini döşek ile yaygı ve sergi şeklinde kullanılan dokumalara yazım adı verildiğini, ancak daha sonraları tülüğ yazım kelimesini bırakarak halı kelimesini kullandıklarını belirtmektedir. Eski Mısır Türkleri ile Kıpçak Türk kültür çevresinde ve hatta Orta Avrupa'daki Kuman Türklerinde, halı şeklinde söylenmekteydi. Selçuklular dönemine ait vakfiyelerde halıya "bastı-bask" denilmekte, XIV. yy.da yazılan Dede Korkut Kitabında halı kelimesinin karşılığı olarak "kalı, kalıça ve kılalıça" kelimeleri kullanılmıştır. XIV. yy. metinlerinde kalı, Osmanlı dönemi metinlerinde kalın, kalı, kaliçe, haliçe, seccâde şeklinde kullanılmakta, daha büyük örneklerine kaliçe-i kebir, küçüklerine de namazlık denilmektedir. Günümüzde ise halı şeklinde söylenmektedir ${ }^{31}$.

Halılar, desenlerine, kullanım amacına ve boyutlarına göre sınıflandırılmaktadır. Bugünkü halıcılığımızda desen çeşitlerini göre halıları üç grupta sınıflandırabiliriz. Bunlar; Mihraplı halılar, Köşeli ve Göbekli halılar, raporlu halılardır. Kullanım amaçlarına ve boyutlarına göre halılar Namazlık halısı, Seccade halısı, Yastık halısı, Duvar halısı, Sedir halısı, Döşek halısı, Taban halısı, Kelle halısı, Somya halısı, Eşik halısı, Minder halısı, Heybe halısı, Torba halısı, Eğer halısı, Semen-Havut halısı olarak sınıflandırılmaktadır.

\subsubsection{Essik Halısı}

Kapı eşiğine sermek için dokunur. Bu nedenle eşik halısı denir. Taban halılarının serilmesinden sonra veya taban halısından arta kalan yerleri doldurmak için de kullanılır. Taban halısı serildiğinde, özellikle, taban halısının yetişmediği yere veya taban halısından önce basılması için kapı eşiğine serilir. Bu nedenle, son zamanlarda, çeyrek halı da denilmektedir. Genellikle, küçük boyludur. Yaklaşık 1-1,5 m² büyüklüğündedir. Özellikle, Batı Anadolu Bölgesinde, Kula, Gördes civarında, İç Anadolu Bölgesi'nde da halının dokunduğu her merkezde görülür. Her yörede

29 R. Genç, “Kaşgarlı Mahmud'a Göre XI. yüzyılda Türklerde Dokuma ve Yaygı İşleri" Türk Soylu Halkların Halı, Kilim ve Cicim Sanatı Uluslararası Bilgi Şöleni Bildirileri, 27-31 Mayıs1996 Kayseri, AKM Yayınları, Ankara 1998, s. 131

30 Bekir Deniz, a.g.e., s. 6.

31 Bekir Deniz, a.g.e., s. 8. 


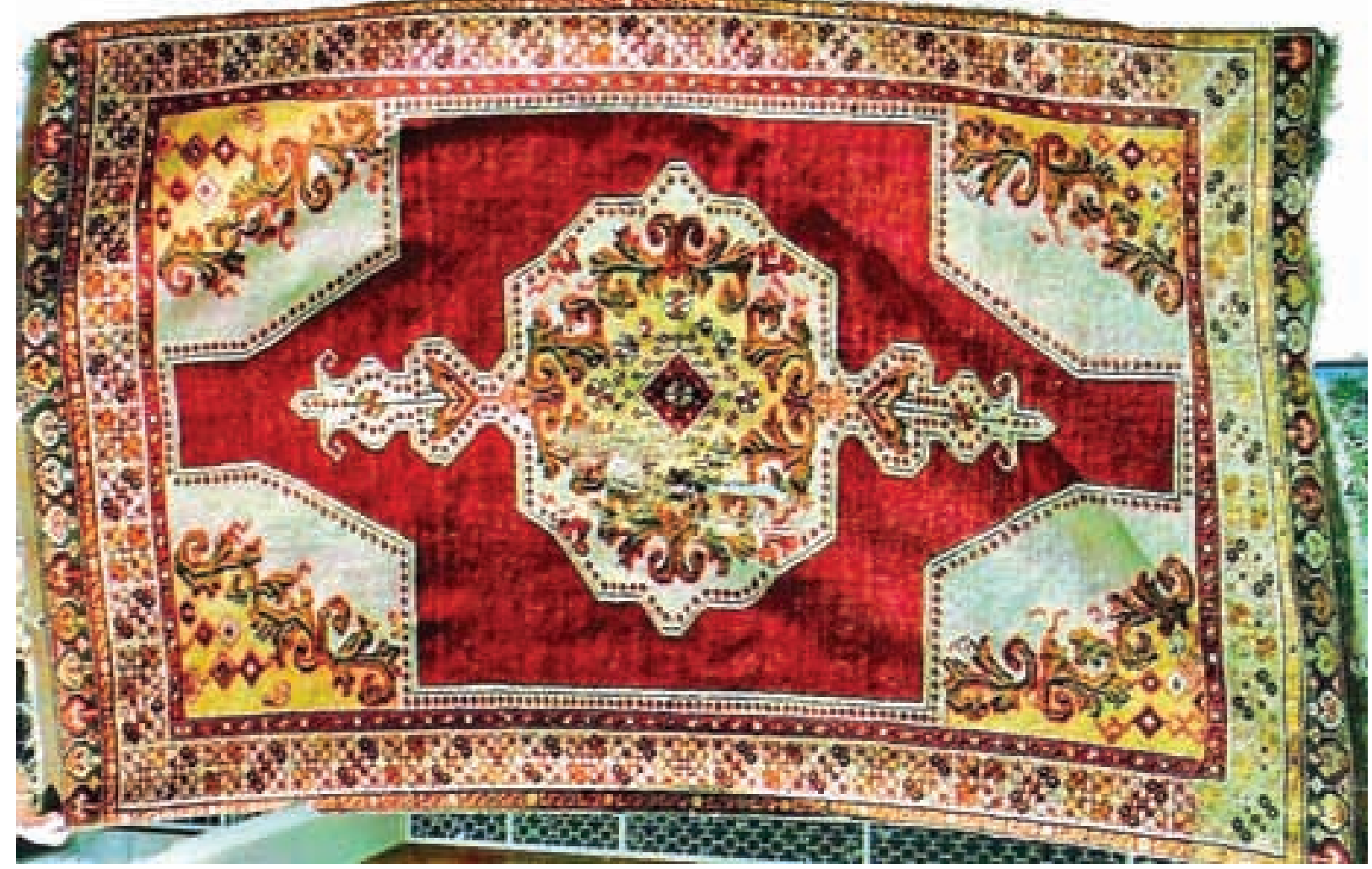

Örnek No/ Fotoğraf No : 1 Elazı̆̆ Müzesi, Envanter No:73/F.34-40 2003

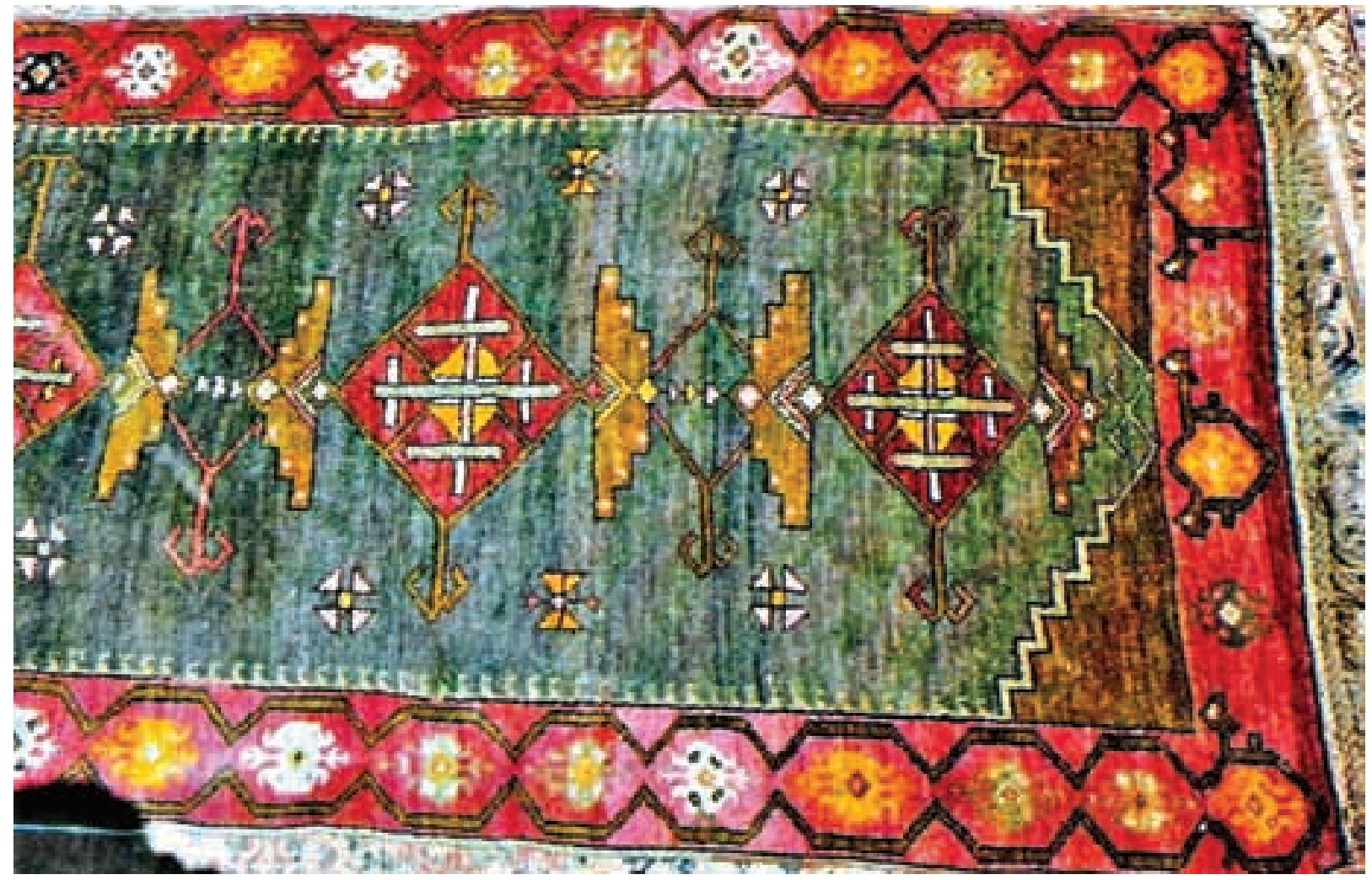

Örnek No/ Fotoğraf No : 2 Elazı̆̆ Müzesi, Envanter No:79/F.7-3 2003 


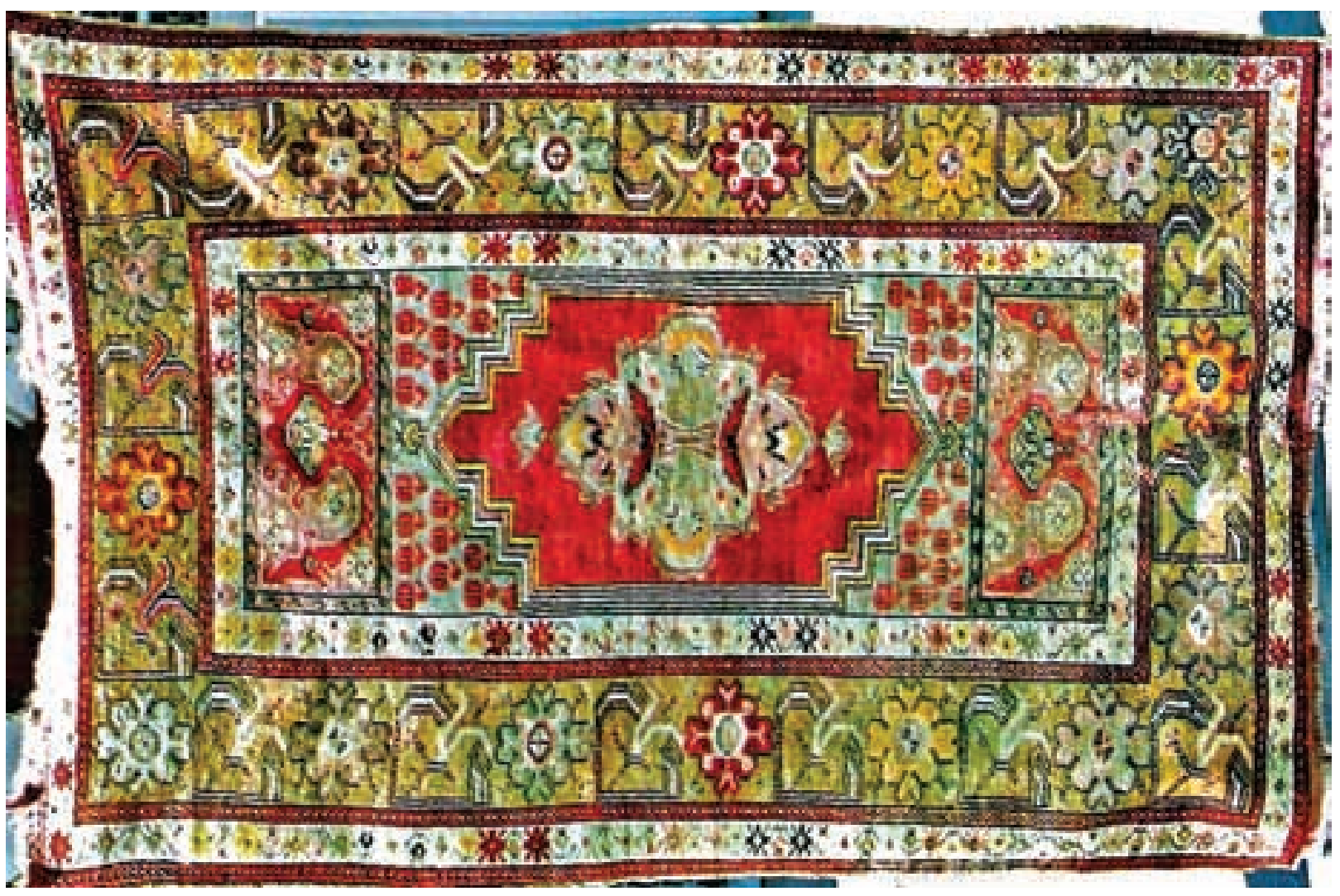

Örnek No/ Fotoğraf No : 3 Elazığ Müzesi, Envanter No:75/F.30-40 2003 farklı desenlerle süslenir. Küçük boyutlu dokunduğu için, deseni farklıdır. (Örnek No: 1, 2, 3).

\subsubsection{Seccade Halısı}

Günümüzde, namazlık halısında büyük, kelle halısından daha küçük, büyük halıların yetmediği yerleri doldurmak üzere dokunmuş her halıya seccade denir. Seccâde namazlık değildir. Ancak mecbur kalındığında, diğer halılara göre daha küçük boyutlu olduğu için kâbe yönüne çevrilip, namaz kılınabilir. Ancak, seccâde, her zaman, serili haldedir. Çoğunlukla $2 \mathrm{~m}^{2}$ ölçülerinde veya daha büyük dokunur. Desen açısından diğer halılara benzer. Mihrap nişi yoktur. Ancak, kaynaklarda yanlış bir isimlendirilmeyle, seccâde namazlık halısıymış gibi anlatılır² (Örnek No:4).

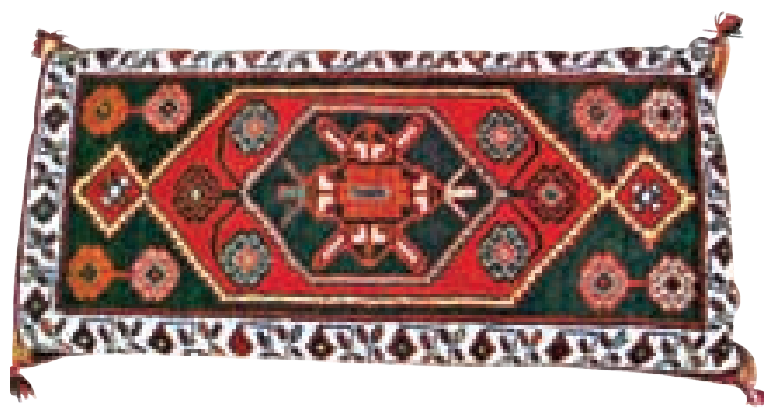

Örnek No/ Fotoğraf No : 4 Elazığ Müzesi, Envanter No:71/F.9-8 2003

32 O. Aslanapa, Türk Halı Sanatının Bin Yilı, İstanbul, 1987, s. 145-212.

\subsubsection{Namazlık Halısı}

Üzerinde namaz kılmak için dokunur. Kullanılmadı̆̆ı zamanlarda, toplanıp bir yerde saklanır. Genellikle bir insanın namaz kılabileceği ölçülerdedir. İçlerinde 100x50-60 cm. boyutlarındaki, 1,5-2 m² arasında değişen örnekleri yaygındır. Diğer halılardan farklı olarak, namaz kılınacak yöne sembolik bir mihrap yapılır. Mihrabın etrafına ibrik motifi işlenebilir. Mihrabın içine yukarıdan aşağıya doğru sarkan, bir kandil yapılır. Bazen kandil çiçek buketi gibi verilir. İbrik temizliği, kandil nur ve ışığı sembolize eder. Bazen, mihrabın altında ve üstünde birer dikdörtgen çerçeve bulunur. Bunlara Ege bölgesinde ayetlik Orta Anadolu Bölgesinde sandık denir. Bu çerçevelerin içine ayet ve tarih yazılır 33 (Eser No:5).

2. Elazığ Müzesindeki Osmanlı Dönemi Eșik ve Seccade Halıları

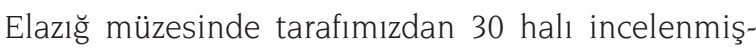
$\operatorname{tir}^{34}$. Bunlardan yastık halıları yayınlanmıştır ${ }^{35}$. Bu bildiride toplam beş adet olan eşik, seccade ve namazlık halısı ele alınacaktır

33 B. Deniz, a.g.e., s. 75.

34 Danışmanlığı tarafımdan yapılmış olan bir yüksek lisans tezi bitirilmiştir. Bkz. A. TÜTEN, Elazığ Müzesindeki Halılar, F.Ü. Sosyal Bilimler Enstitüsü, Yayınlanmamış Yüksek Lisans Tezi, Elazı̆̆ 2004.

35 A. Tüten, "Şafak Yastık Halıları", Şafak Bülteni, S.20, Elazığ 2004, s.11-15 


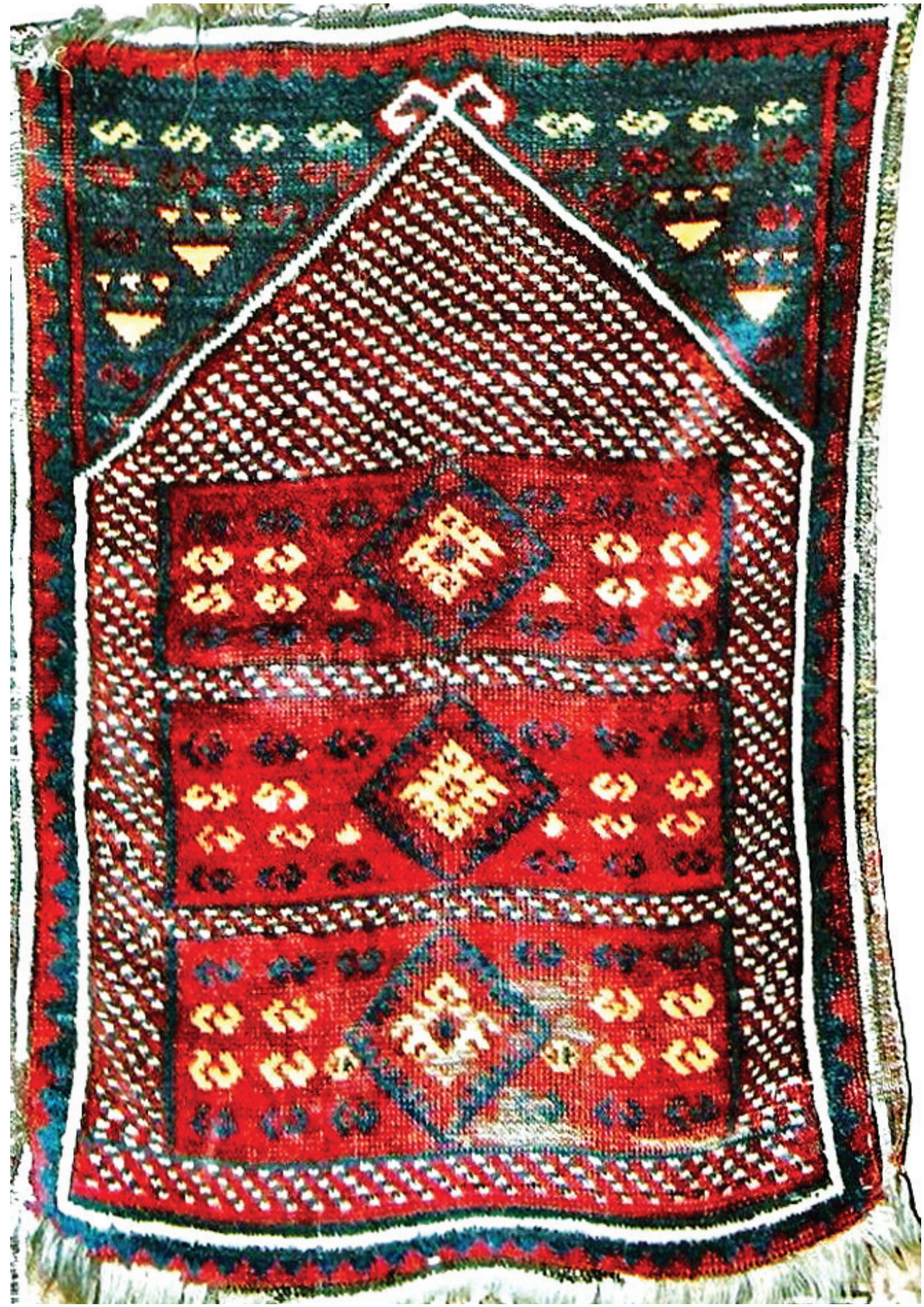

Örnek No/ Fotoğraf No : 5 Elazığ Müzesi, Envanter No:74/F.41-1 2003 
İsmail AYTAÇ

\subsection{Esik Halıları}

Örnek No : 1

Örneğin Adı : Bitkisel desenli madalyonlu eşik halısı.

Fotoğraf No : $1,1,1$,

Şekil No

Envanter No

$: 2,4,6,8,14$

: 73/F.34-40

Koleksiyona Geliş Tarihi

Koleksiyona Geliş Biçimi

Koleksiyondaki Yeri

İnceleme Tarihi

: 08/10/1973

: Süleyman YURTEN'den satın alınmıştır.

: Elazığ Müzesinde 2. Katta Gelin Odasında sergilenmektedir.

: Temmuz 2003

: Akdağı Madeni (Konya- Kırşehir)

: 19.Yüzyılın ikinci yarısı.

: Kitabesi yoktur.

: Zemin kısmı sökülmüş durumda

: Göbek kısmı örülmüştür.

: Eni $103 \mathrm{~cm}$., Boyu $170 \mathrm{~cm}$.

: 1 Bordür $1 \mathrm{~cm}, 2$.Bordür $\quad 12,5 \mathrm{~cm}, 3$.Bordür $1 \mathrm{~cm}$

: $12,5 \mathrm{~cm}$

: Atkı, çözgü ve düğüm iplerinde yün kullanılmıştır.

: Türk (Gördes) düğümü kullanılmıştır.

Uygulanan Teknik

Dokuma Yoğunluğu (10 mm²'de) : 115 düğüm bulunmaktadır.

Düğüm Sayısı (YatayxDikey) : 11 x 10

Hav Yüksekliği $\quad: 5 \mathrm{~mm}$

Kullanılan Renkler :

Atkı

Çözgü

Süsleme

Kullanılan Motifler

Kompozisyon

Değerlendirme
: Kahverengi

: Bej

: Kırmızı, beyaz, siyah, yeşil, turuncu, kahverengi, sarı.

: Geometrik çiçek, asma filizleri, göz, hayat ağacı, yıldız, puan, çengel (S) motifleri.

: Halının zeminine; kırmızı üzerine merkezi sekiz köşeli bir yıldız çiçeği (Şekil No:8) çevresi simetrik şekilde işlenmiş stilize çiçeklerle (Şekil No:14) dolgulu, kartuşlu bir madalyon yerleştirilmiştir. Madalyon ve kartuşların iç kenarları; sıralı puanlarla süslenmiştir. Kırmızı, beyaz, yeşil, sarı, siyah ve kahverengi renkler kullanılmıştır. Köşeler ve iç bordür; ince bir şerit ve sıralı puanlarla zeminden ayrılmıştır. Köşeler; stilize çiçekler, göz ve asma filizleri ile bezenmiştir ${ }^{36}$. Madalyonun uç kısımlarında eli belinde (Şekil No:6) motifi yer almıştır. İç kısmında hayat ağacı (Şekil No:4), göz (Şekil No:2), yıldız (Şekil No:8) ve stilize çiçek motifleri ile süslenmiştir ${ }^{37}$. Göz motifleri nazara karşı korunma amaçlıdır. Yıldız motifi mutluluğu ifade etmektedir. Halının bordürleri kırmızı, beyaz, yeşil ve siyah zemin geometrik çiçek, meşe mazısı, yaprak ve çengel motifleri ile süslenmiştir. Bu halı bir bütün olarak "Cennet Bahçesinin" sembolik bir ifadesidir ${ }^{38}$.

: Bitkisel desenli bu halının atkı, çözgü ve düğüm ipliğinde yün malzeme kullanılmıştır. Gördes düğümü kullanılan halıda, 10 mm²'de 115 düğüm bulunmaktadır. Kullanılan renk ve motiflerin benzerliği yönüyle Akdağı Madeni (Konya-Kırşehir) yöresine ait olduğu sanılmaktadır. Kitabesi olmadığı için kesin bir tarihlendirme yapmak mümkün değildir. 19. yüzyılın ikinci yarısında dokunduğu tahmin edilmektedir.

36 Stilize çiçekler için bkz. N. Görgünay, Doğu Yöresi Halıları, Türkiye İş Bankası Kültür Yayınları, Ankara (Tarihsiz) s. 108

37 Bitkisel motifler için bkz. F. Memişoğlu, Harput'ta Gelenekler, Inançlar ve El Sanatı, Ankara, 2006, s.76-90

38 Anonim, Türk El Dokuması Halılar. T.C. Kültür Bakanlığı C.4. Mod. Kod. 386. Ankara, 1998. 

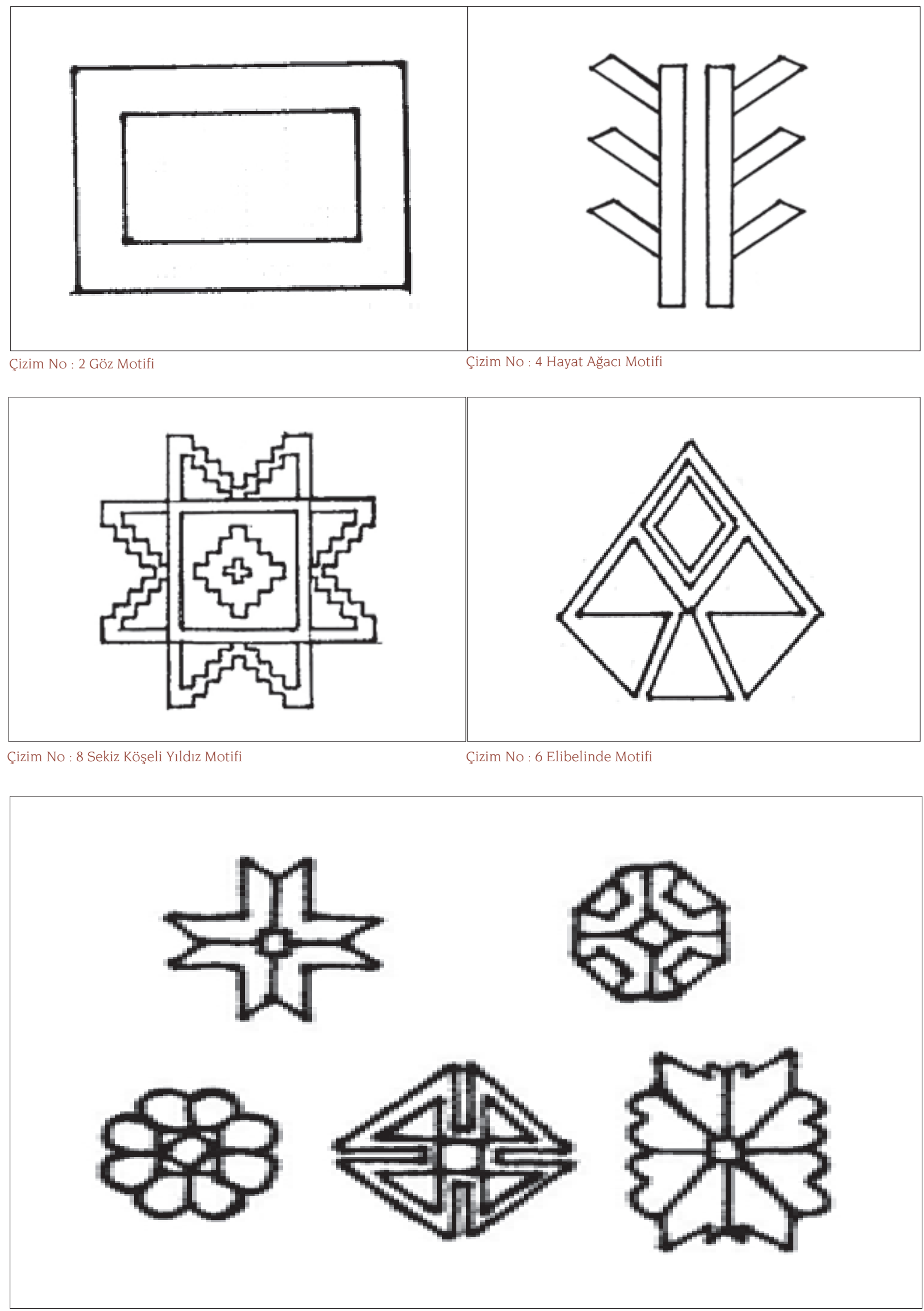
İsmail AYTAÇ

Örnek No
Örneğin Adı
Fotoğraf No
Şekil No
Envanter No
Koleksiyona Geliş Tarihi
Koleksiyona Geliş Biçimi
Koleksiyondaki Yeri
Inceleme Tarihi
Kaynaklara Göre Yöresi
Ürünün Yapılış Tarihi
Kitabesi
Bugünkü Durumu
Onarım Görüp Görmediği
Boyutları
Bordür Eni
Kullanılan Malzeme
Uygulanan Teknik
Dokuma Yoğunluğu (10 mm2'de)
Düğüm Sayısı (Yatay Dikey)
Hav Yüksekliği
Kullanılan Renkler
Atkı
Çözgü
Süsleme
Kullanılan Motifler

Kompozisyon

Değerlendirme

\section{2}

:Geometrik desenli dikdörtgen madalyonlu eşik halısı

$: 2$

$2,3,5,7,14,15,17$

:79/F.7-3

$-1979$

: İ. Halil GÖNDOĞDU'dan satın alınmıştır.

: Elazığ Müzesi deposunda muhafaza edilmektedir

Temmuz 2003

: Sivas

20. Yüzyılın ortaları

Kitabesi yoktur.

: Yıpranmamış durumda

Onarım görmemiştir

: Eni $101 \mathrm{~cm}$, Boyu $261 \mathrm{~cm}$

: 1. Bordür $2 \mathrm{~cm}, 2$. Bordür $15 \mathrm{~cm}$

: Atkı, çözgü ve düğüm ipliğinde yün ve pamuk kullanılmıştır.

: Gördes düğüm tekniği kullanılmıştır.

60 adet düğüm bulunmaktadır.

$10 \times 6$

$: 11 \mathrm{~mm}$

Beyaz

Bej

Ceviz yeşili, pembe, bordo, beyaz, turkuaz, sarı, siyah, kahverengi

Koçboynuzu, çiçek, akarsu, baklava, saç bağı, koşan köpekler motifleri

: Halının zemininde, turkuaz üzerine yeşil, bordo, sarı, kahverengi, pembe, renklerle oluşturulmuş geometrik motifler kullanılmıştır. İki ucu koçboynuzlu (Şekil No:3,5) baklava (Şekil No:7) motifleriyle süslenmiştir. Koçboynuzu motifi, doğurganlığı simgelemektedir. Ayrıca zeminde yer alan, geometrik çiçek (Şekil No: 14) motifleri “Cennet Bahçesini” temsil etmektedir. Saç bağı (Şekil No: 15) motifi evlilik isteğini belirtmektedir. Zeminde kullanılan göz (Şekil No: 2) motifleri ise nazara karşı korunma amaçlıdır. Zeminin uzun kenarları, koşan köpekler (Şekil No: 17) motifiyle süslenmiştir. Halının bordürleri, geometrik çiçek ve konturle oluşturulmuş akarsu motifleriyle süslenmiştir.

: Bu taban halısının atkı, çözgü ve düğüm ipliklerinde yün malzeme kullanılmıştır. Gördes düğüm tekniğiyle dokunmuştur. Halının renk ve süslemesindeki motiflerin benzerliği yönüyle Sivas yöresine ait olduğu bilinmektedir. Kitabesi olmadığı için kesin bir tarihlendirme yapmak mümkün değildir. 20. yüzyılın ortalarında dokunduğu sanılmaktadır. 


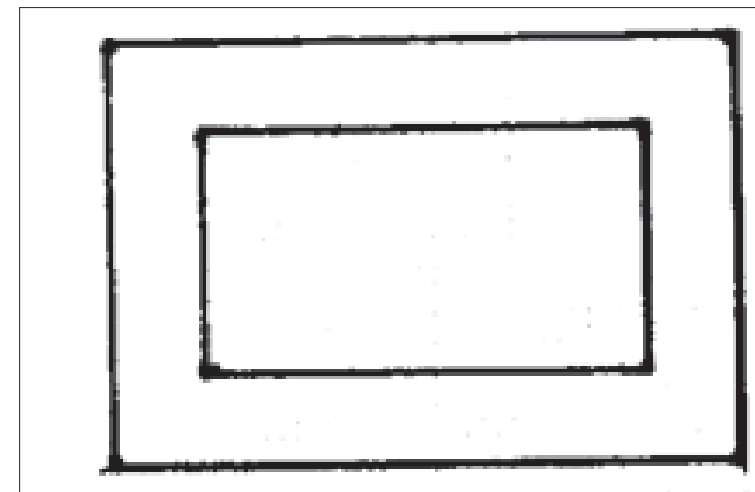

Çizim No : 2 Göz Motifi

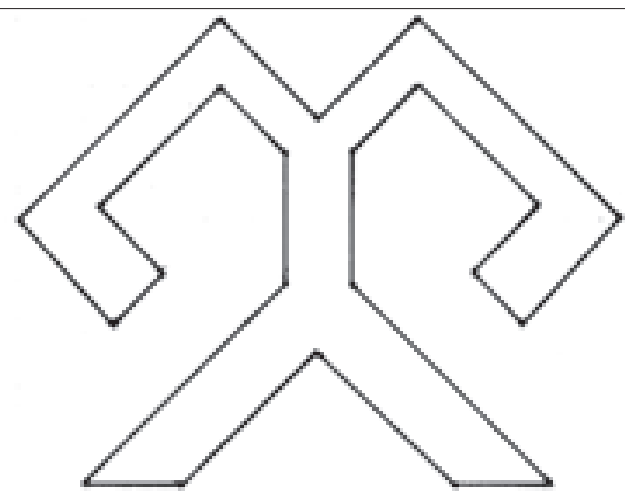

Çizim No : 3 Koçboynuzu Motifi

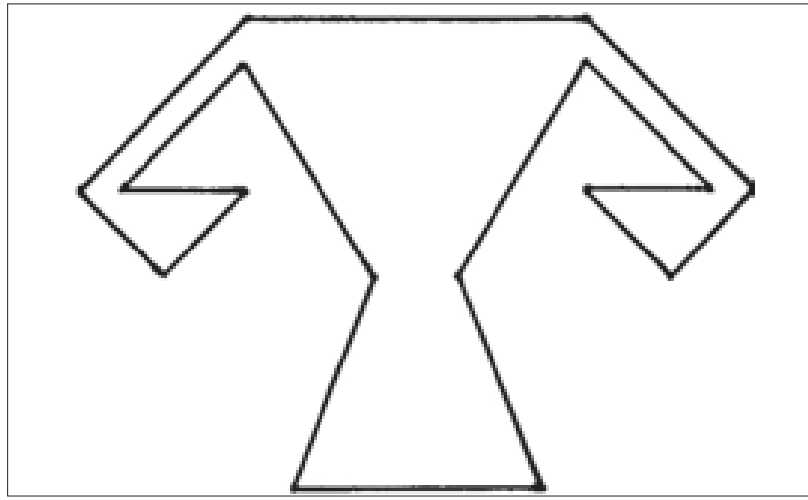

Çizim No : 5 Koçboynuzu Motifi

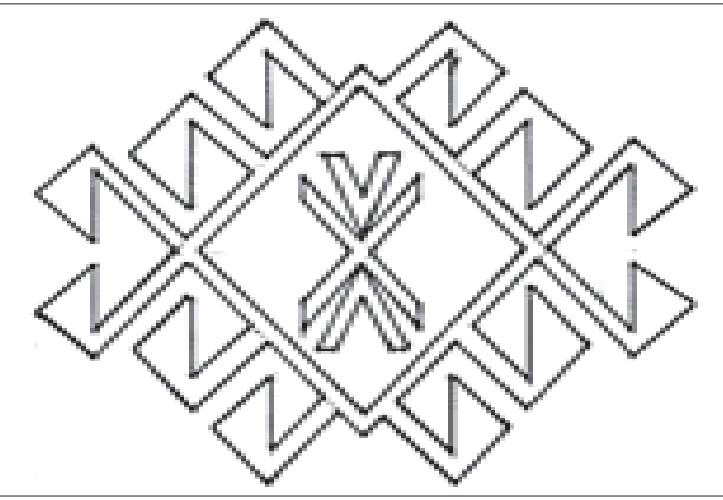

Çizim No : 7 Çengelli Baklava (Akrep) Motifi

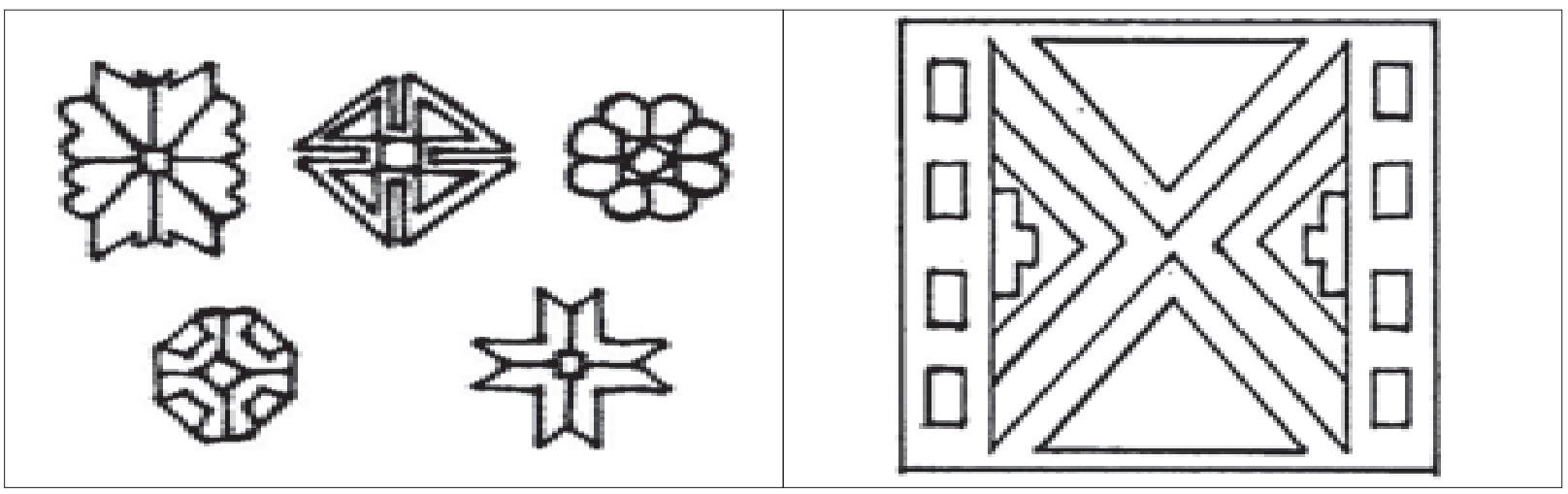

Çizim No : 14 Çiçek-Gül Motifi

Çizim No : 15 Saç Bağı Motifi

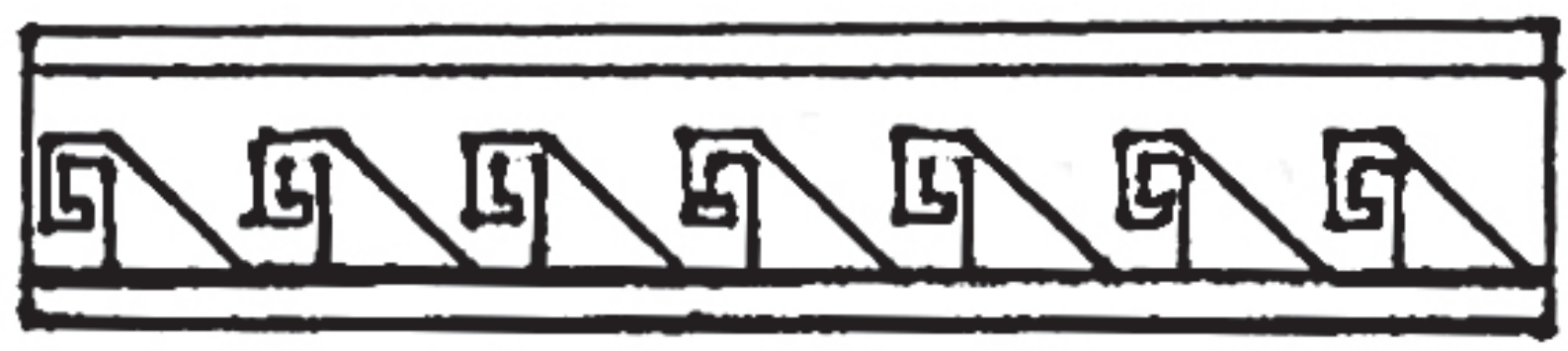

Çizim No : 17 Koşan Köpekler Motifi 
İsmail AYTAÇ

\begin{tabular}{|c|}
\hline Örnek No \\
\hline Örneğin Adı \\
\hline Fotoğraf No \\
\hline Şekil No \\
\hline Envanter No \\
\hline Koleksiyona Geliş Tarihi \\
\hline Koleksiyona Geliş Biçimi \\
\hline Koleksiyondaki Yeri \\
\hline İnceleme Tarihi \\
\hline Kaynaklara Göre Yöresi \\
\hline Ürünün Yapılış Tarihi \\
\hline Kitabesi \\
\hline Bugünkü Durumu \\
\hline Onarım Görüp Görmediği \\
\hline Boyutları \\
\hline Bordür Eni \\
\hline Diğer Bordürler \\
\hline Kullanılan Malzeme \\
\hline Uygulanan Teknik \\
\hline Dokuma Yoğunluğu (10 mm2'c \\
\hline Düğüm Sayısı (YatayxDikey) \\
\hline Hav Yüksekliği \\
\hline Kullanılan Renkler \\
\hline Atk1 \\
\hline Çözgü \\
\hline Süsleme \\
\hline Kullanılan Motifle \\
\hline
\end{tabular}

Kompozisyon

Değerlendirme

\section{$: 3$}

: Bitkisel desenli altıgen madalyonlu eşik halısı.

: $3,3.1$

: $4,5,8,11,14,16$

: 75/F.30-40

: 09/07/1975

: Tahsin EMiK'ten satın alınmıştır.

: Elazı̆̆ Müzesi 2. Katta Halı Teşhir Salonunun Gelin Odası bölümünde sergilenmektedir.

: Haziran 2003

: Kırşehir (Mucur)

: 19.yüzyılın başları

: Kitabesi yoktur

: Enine 4,5,6 bordürler dikilmiştir.

: Onarım görmüştür.

: Eni $107 \mathrm{~cm}$, Boyu $165 \mathrm{~cm}$

: 1 .Bordür $2 \mathrm{~cm}, 2$.Bordür $5 \mathrm{~cm}, 3$. Bordür $15,5 \mathrm{~cm}$

: $2 \mathrm{~cm}, 5 \mathrm{~cm}$

: Atkı, çözgü ve düğüm ipliğinde yün ve pamuk kullanılmıştır.

: Gördes düğüm tekniği kullanılmıştır.

: 103 adet düğüm bulunmaktadır.

$: 10 \times 10$

: $6 \mathrm{~mm}$

:

: Beyaz

: Bordo

: Yeşil, kırmızı, siyah, beyaz, sarı, pembe, kahverengi renkler kullanılmıştır.

: Hayat ağacı, ejderha, çiçek, çarpı, küçük su motifleri

: Bu halı, bütün olarak "Cennet Bahçesini" sembolize etmektedir. Halının kırmızı zemini üzerine; merkezi sekiz köşeli bir yıldız çiçeği (Şekil No: 8) çevresi simetrik şekilde işlenmiş stilize çiçeklerle (Şekil No: 14) dolgulu, kartuşlu bir madalyon yerleştirilmiştir. Madalyonun içi, stilize edilmiş hayat ağacı (Şekil No:4) motifi ile süslenmiştir. Etrafı sarı, pembe, beyaz ve yeşil renkte konturlerle sınırlandırılmıştır. Madalyonun köşe kısımlarında, kırmızı renkli geometrik çiçek motifleri ile süslenmiştir. Madalyonun her iki ucunda hayat ağacını koruyan kırmızı renkli ejderha (Şekil No: 11) motifleri kullanılmıştır. Hayat ağacı ruhun ölümsüzlüğünü ve sonsuzluğunu simgelemektedir. Halının içten 1. ve 5 . bordürlerinde, beyaz zemin üzerine kırmızı, siyah, pembe, sarı renklerle oluşturulmuş çarpı (Şekil No:16) motifi ile çiçek (Şekil No: 5) motifleri kullanılmıştır. Çarpı motifi nazara karşı korunma amaçlıdır. 2.4. ve 6. bordürlerde, pembe renk üzerine siyah ve beyazlarla küçük su motifi ile süslenmiştir. 3 . bordür, yeşil zemin üzerine siyah, sarı, kırmızı, beyaz, pembe renklerle oluşturulmuş geometrik çiçek ve yaprak motifleri ile desenlendirilmiştir.

: Bu eşik halısında, malzeme olarak atkı, çözgü ve düğüm ipliğinde yün ve pamuk kullanılmıştır. Gördes düğüm tekniğiyle dokunan bu halı orta kalitededir. Kullanılan renk ve motiflerin benzerliği yönüyle Kırşehir yöresine ait olduğu bilinmektedir. Kitabesi olmadığı için 19. yüzyılın başlarında dokunduğu sanılmaktadır. 

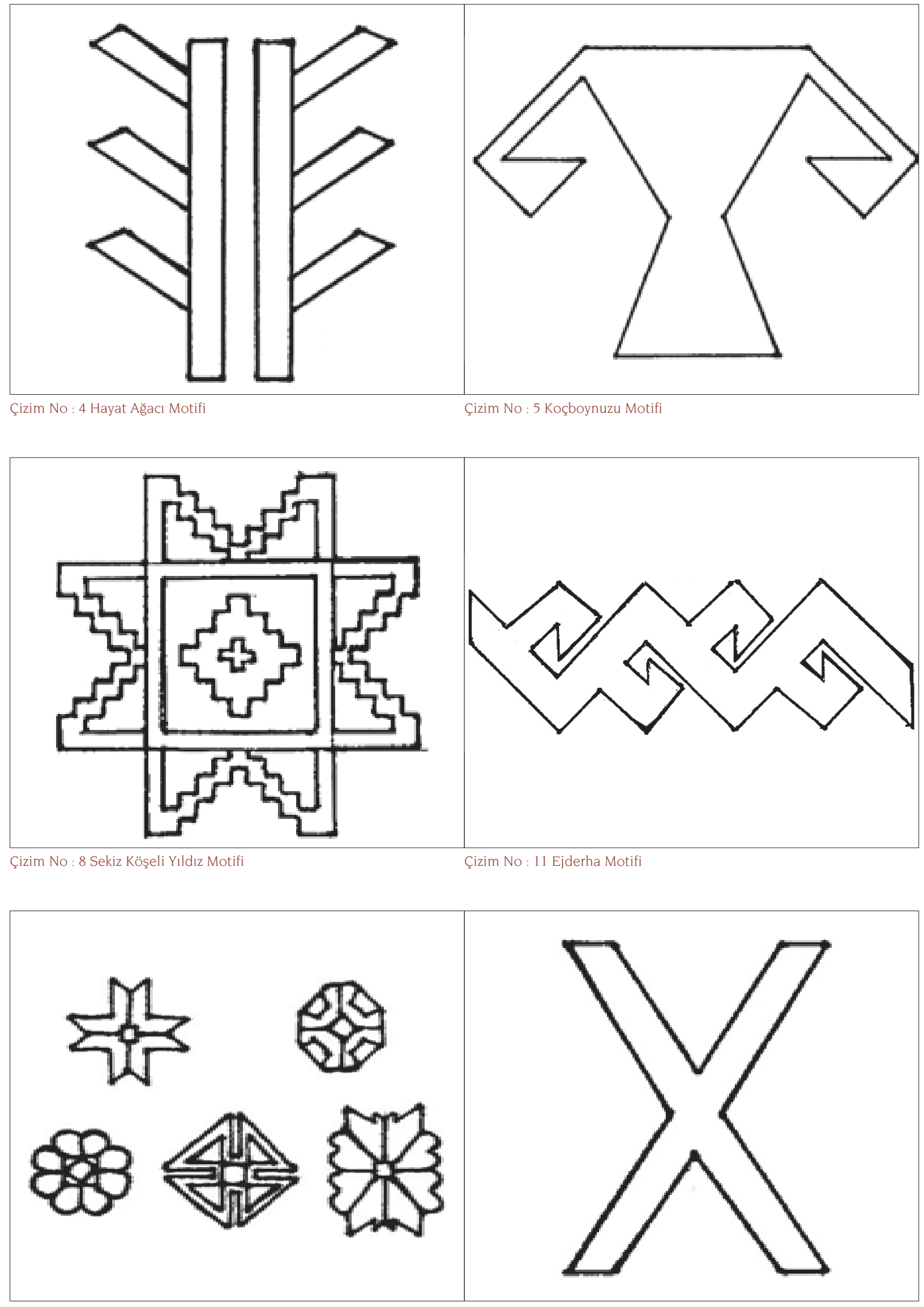
İsmail AYTAÇ

\author{
2.2. Seccade Halısı \\ Örnek No \\ Örneğin Adı \\ Fotoğraf No \\ Şekil No \\ Envanter No \\ Koleksiyona Geliş Tarihi \\ Koleksiyona Geliş Biçimi \\ Koleksiyondaki Yeri \\ İnceleme Tarihi \\ Kaynaklara Göre Yöresi \\ Ürünün Yapılış Tarihi \\ Kitabesi \\ Bugünkü Durumu \\ Onarım Görüp Görmediği \\ Boyutları \\ Bordür Eni \\ Kullanılan Malzeme \\ Uygulanan Teknik \\ Dokuma Yoğunluğu (10 mm2'de) : 81 düğüm bulunmaktadır \\ Düğüm Sayısı (YatayxDikey) : 10x8 \\ Hav Yüksekliği \\ Kullanılan Renkler \\ Atkı \\ Çözgü \\ Süsleme \\ Kullanılan Motifler \\ $: 4$ \\ : Mihrap desenli üç kişilik seccâde halısı \\ $: 4$ \\ $: 2,6,7,10,12,13,14,18,20$ \\ : $71 /$ F.9-8 \\ 23/02/1971 \\ : Mahmut BELHAN'dan satın alınmıştır. \\ : Elazığ Müzesi deposunda muhafaza edilmektedir. \\ : Kasım 2003 \\ : Sivas \\ : 19.Yüzyılın ilk yarısı. \\ : Kitabesi yoktur. \\ : Kısa kenar bordürleri yırtılmıştır. Zemin kısmı aşınmıştır. \\ : Onarım görmemiştir. \\ : Eni $121 \mathrm{~cm}$, Boyu $148 \mathrm{~cm}$ \\ : 1 . Bordür $2 \mathrm{~cm}, 2$. Bordür $5 \mathrm{~cm}, 3$. Bordür $15,5 \mathrm{~cm}$ \\ : Atkı, çözgü ve düğüm iplerinde yün kullanılmıştır. \\ : Türk (Gördes) düğüm tekniğiyle dokunmuştur. \\ : $3 \mathrm{~mm}$ \\ : Beyaz \\ : Beyaz \\ : Kırmızı, siyah, mavi, yeşil, turuncu, beyaz, sarı. \\ : Mihrap, karanfil, akrep, göz, elibelinde, bereket ve sedefler.
}

Kompozisyon

Değerlendirme

39 Anonim, Türk El..., C.4. Mod. Kod. 339.
: Bu üç kişilik bir saf seccadesidir. Zemin kısmı, kırmızı, yeşil ve mavi renklerle oluşturulmuştur. Zeminde kontürlerle oluşturulmuş mihraplar (Şekil No:18) bulunmaktadır. Mıhrapların iç ve dış kısımları muska (Şekil No:13), karanfil (Şekil No:20), göz (Şekil No:2) ve akrep (Şekil No:7) motifleriyle süslenmiştir. Muska, göz ve akrep motifleri nazara karşı korunma amaçl1dır. Karanfil ve dış bordürde kullanılan gül motifleri ise "Cennet Bahçesini" simgelemektedir. Mihrapların uç kısmında elibelinde (Şekil No:6) motifi ile doğurganlığı temsil etmektedir ${ }^{39}$. Halının içten dışa doğru bordürlerinde, akrep, bereket (Şekil No:12), sedefler (Şekil No:10) ve gül (Şekil No:14) motifleri kullanılmıştır. Bordür motifleri mavi, kırmızı ve turuncu üzerine siyah, turuncu, sarı, beyaz, mavi ve yeşil renklerle oluşturulmuştur. Halının bütününde sıcak ve soğuk renklerle güzel bir uyum oluşturulmuştur.

: Mihrap desenli bu üç kişilik saf seccâdesinin bütününde yün malzeme kullanılmıştır. Gördes düğüm tekniğiyle dokunmuştur. $10 \mathrm{~mm}^{2}$ de 81 düğüm bulunmaktadır. Kullanılan motiflerin benzerliği yönüyle Sivas yöresine ait olduğu bilinmektedir. 19. yüzyılın ilk yarısında dokunduğu fakat kitabesi olmadığı için kesin bir tarihlendirme yapmak mümkün değildir. 

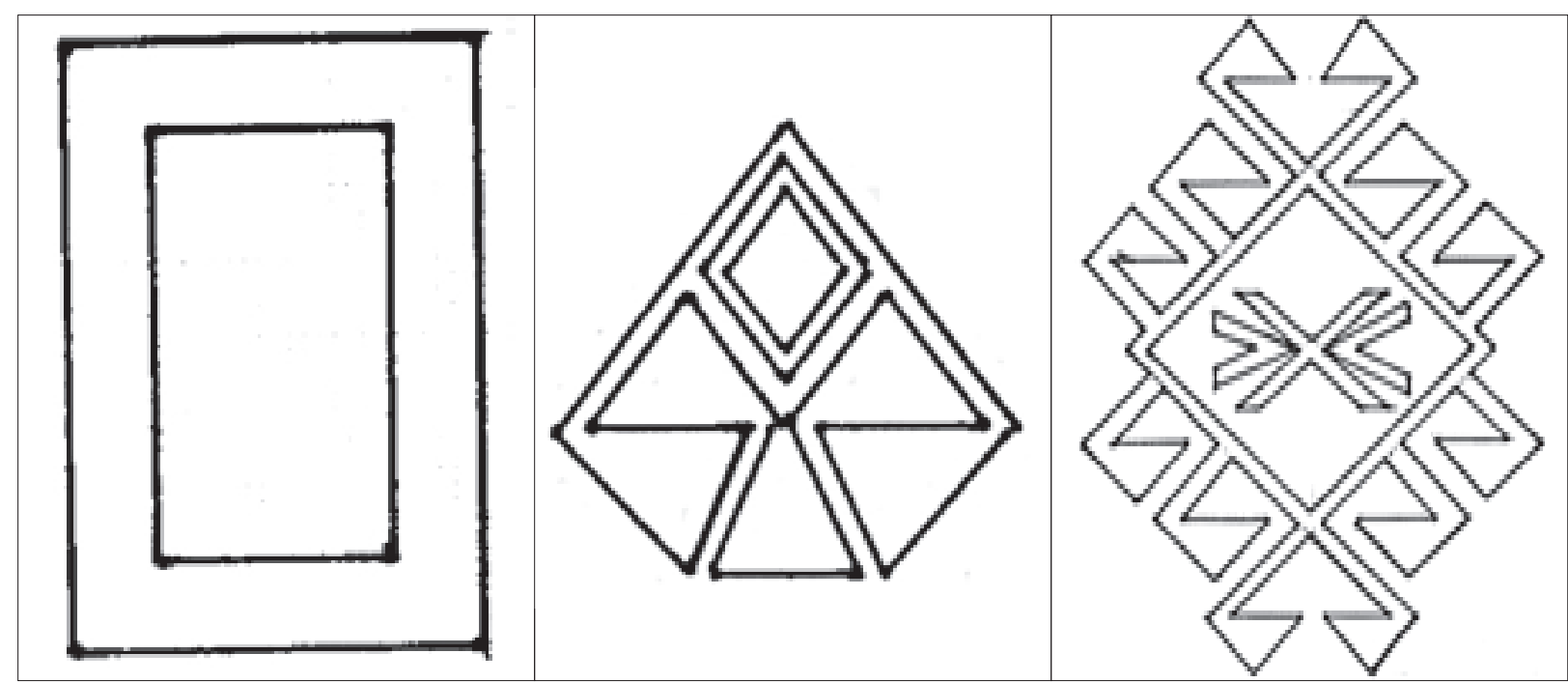

Çizim No : 2 Göz Motifi

Çizim No : 6 Elibelinde Motifi

Çizim No : 7 Çengelli Baklava (Akrep) Motifi

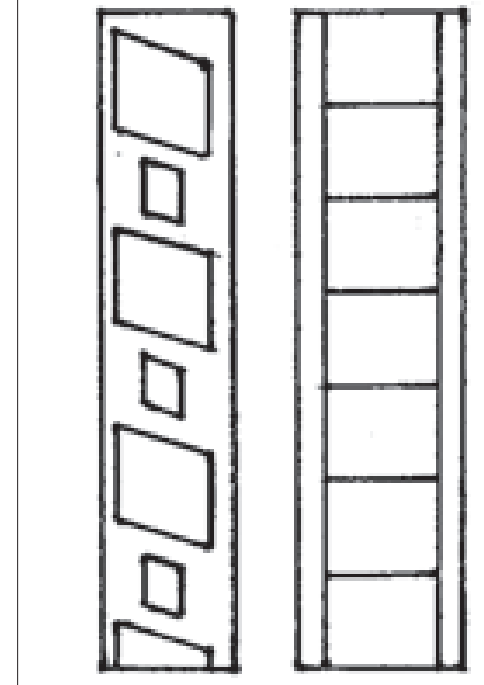

Çizim No : 10 Sedefler Motifi

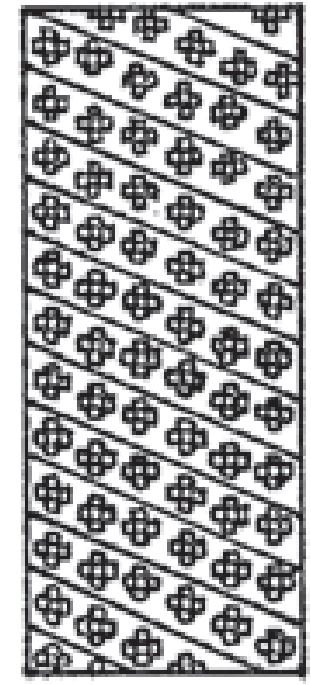

Çizim No : 12 Bereket Motifi

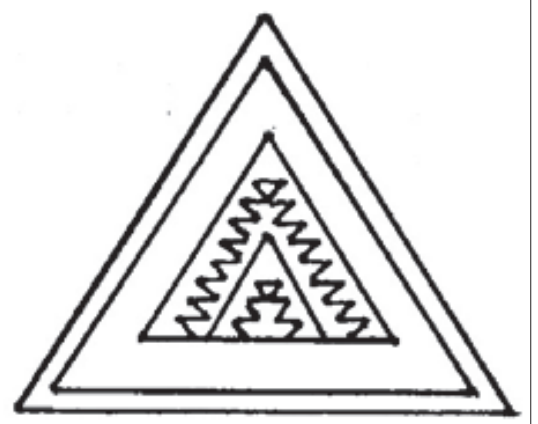

Çizim No : 13 Muska Motifi

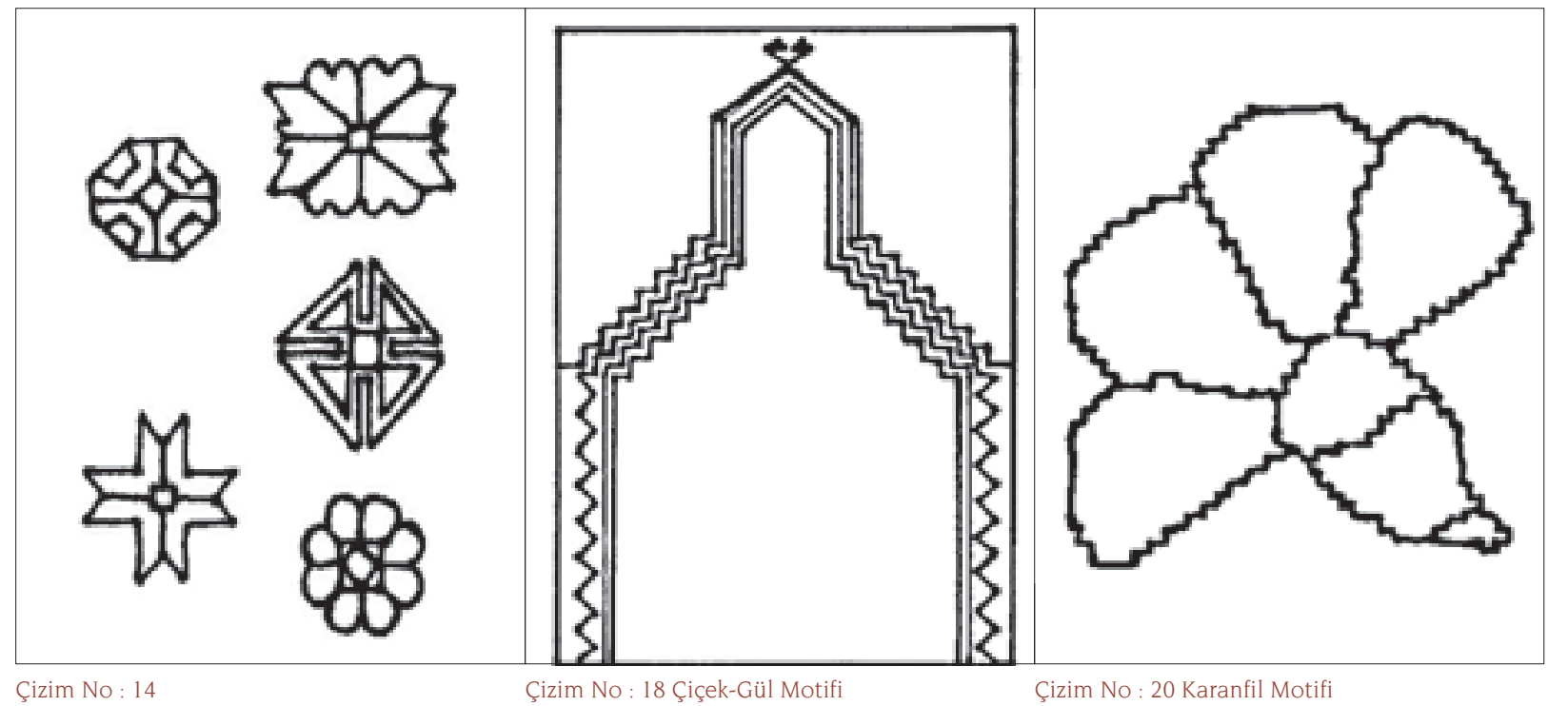


İsmail AYTAÇ

\subsection{Namazlık Halısı}

\section{Örnek No}

Örneğin Adı

Fotoğraf No

Şekil No

Envanter No

Koleksiyona Geliş Tarihi

Koleksiyona Geliş Biçimi

Koleksiyondaki Yeri

\section{İnceleme Tarihi}

Kaynaklara Göre Yöresi

Ürünün Yapılış Tarihi

Kitabesi

Bugünkü Durumu

Onarım Görüp Görmediği

Boyutları

Bordür Eni

Kullanılan Malzeme

Uygulanan Teknik

Dokuma Yoğunluğu (10 mm² de)

Düğüm Sayısı (YatayxDikey)

Hav Yüksekliği

Kullanılan Renkler

Atk1

Çözgü

Süsleme

Kullanılan Motifler

Kompozisyon

Değerlendirme
: 5

: Mihrap desenli namazlık halısı

: 5

$1,9,10,13,18,19$

: $74 / \mathrm{F} .41-1$

:18/12/1974

Kamer ÇÖTELİ'den satın alınmıştır.

Elazığ Müzesi 2. Katta Kuzey koridorunda tahta platformda sergilenmektedir.

Nisan 2004

Elazı̆̆

19. yüzyılın ortaları

Kitabesi yoktur.

:Halının zemin ve bordürleri yıpranmış durumdadır

: Onarım görmemiştir.

: Eni $73 \mathrm{~cm}$, Boyu $105 \mathrm{~cm}$

1.Bordür $1 \mathrm{~cm}, 2$.Bordür $4 \mathrm{~cm}, 3$. Bordür $1 \mathrm{~cm}$

Atkı, çözgüsünde yün, düğüm iplerinde ise yün ve pamuk kullanılmıştır.

Gördes Düğüm tekniği kullanılmıştır.

67 düğüm bulunmaktadır.

$10 \times 7$

$10 \mathrm{~mm}$

Bej

: Bej

: Kırmızı, siyah, beyaz, sarı, lacivert

: Muska, S (çengel), dulavratotu, mihrap, koçboynuzu, bıçkır, sedef, bereket motifleri kullanılmıştır.

: Seccade halısı olduğu için zemine beyaz renkle mihrap (Şekil No:18) yerleştirilmiştir. Mihrabın iç kısmı dikdörtgenler ile üç bölüme ayrılmıştır. Lacivert ile konturlenen bu dikdörtgenlerin iç kısmına kırmızı zemin üzerine sarı ve lacivert renklerle muska ${ }^{40}$ ( Şekil No:13), S (çengel) (Şekil No:1) ve dulavratotu ${ }^{41}$ (Şekil No:19) motifleriyle süslenmiştir. Dulavratotu motifi, doğurganlığı simgelemekte olup; S (çengel) ve muska motifleri ise nazara karşı korunma amaçlıdır. Dikdörtgen bölümlerin etrafında ve mihrabın iç kısmında mavi, kırmızı ve beyaz renklerle oluşturulmuş sedef ${ }^{42}$ (Şekil No: 10) motifi kullanılmıştır. Mihrabın uç kısmı eril doğurganlığı simgeleyen koçboynuzu ${ }^{43}$ motifiyle süslenmiştir. Sedef motifi bazı kaynaklarda bereket ${ }^{44}$ motifi olarak geçmekte olup bolluğu simgelemektedir. Mihrabın her iki tarafında ise yine korunma amaçlı muska ve S (çengel) motifleri kullanılmıştır. Kenarsuyunda ise kırmızı, lacivert ve siyah renklerle oluşturulmuş bıçkır (Şekil No:9) motifi yer almıştır. Bıçkır motifinin etrafı beyaz renkle konturlenmiştir.

: Bu seccade halısının atkı, çözgü ve düğüm iplerinde yün malzeme kullanılmıştır. Kullanılan motiflerin tüm yörelerde kullanılan motiflere benzerliği yönüyle herhangi bir yöre tespiti mümkün olmamakla beraber bazı motifler yönüyle Elazı̆̆ (Şavak) yöresi olduğu sanılmaktadır. 19. yüzyılın ortalarında dokunduğu fakat kitabesi olmadığı için kesin bir tarihlendirme yapmak mümkün olmamıştır.

40 Anonim, Türk El Dokuması Halılar, Mod. Kodu:400.

41 Anonim, Türk El Dokuması Halılar, Katalog No:4 Mod. Kodu:370, 376, 400

42 Sedef motifi için bkz. A. KAFALILAR, Halıcılık Teknolojisi, Ankara, Aralık 1982, s. 55.

43 Anonim, Türk El ..., Mod Kodu: 377.

44 Anonim, Türk El ...., Mod. Kodu: 400. 


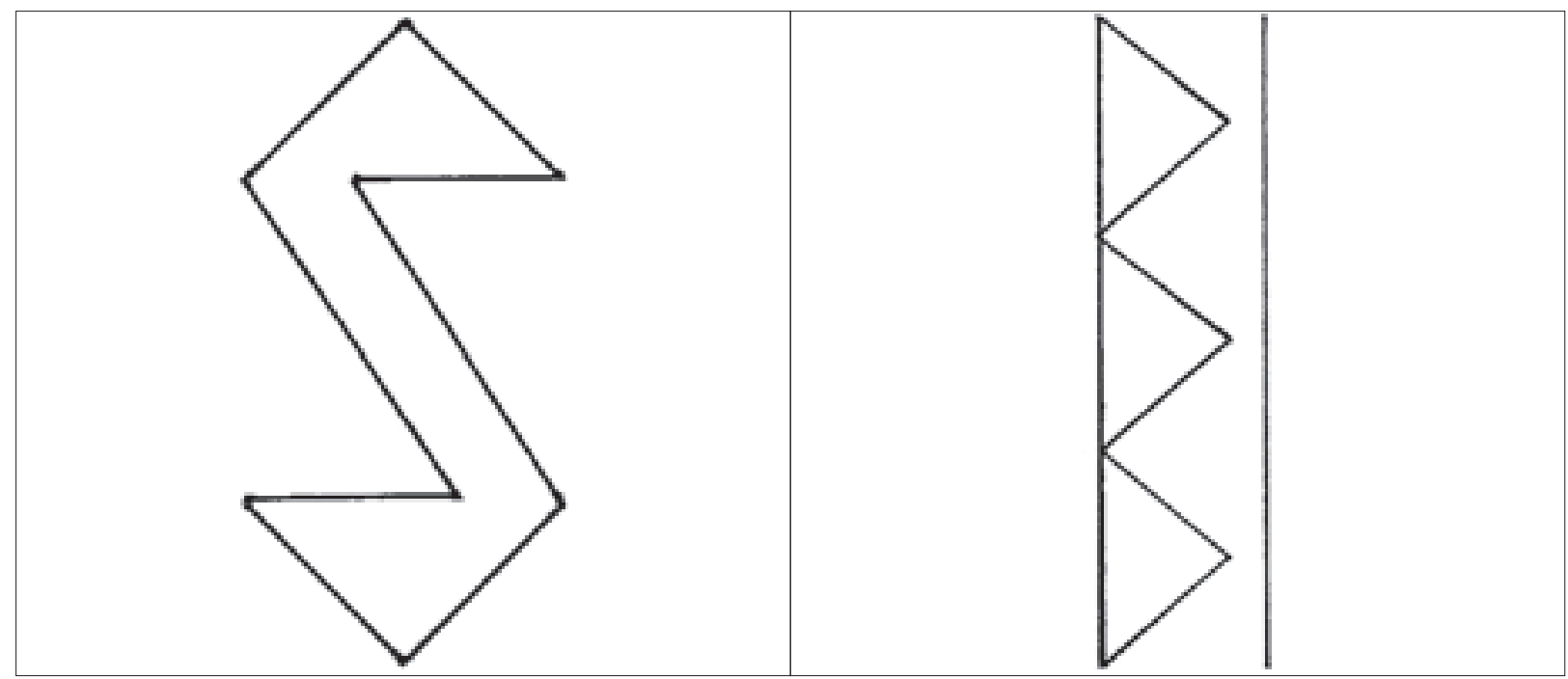

Çizim No : 1 Kuş -S- Burnu Eğri-Çengel Motifi

Çizim No : 9 Bıçkır Motifi

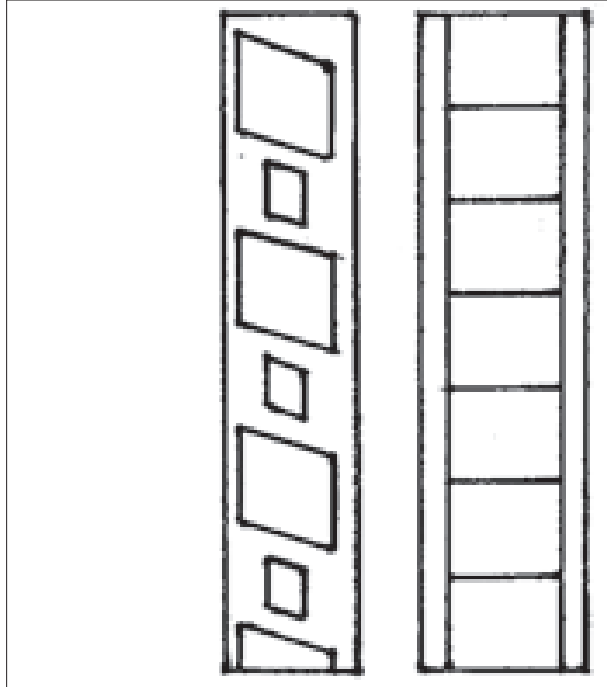

Çizim No : 10 Sedefler Motifi

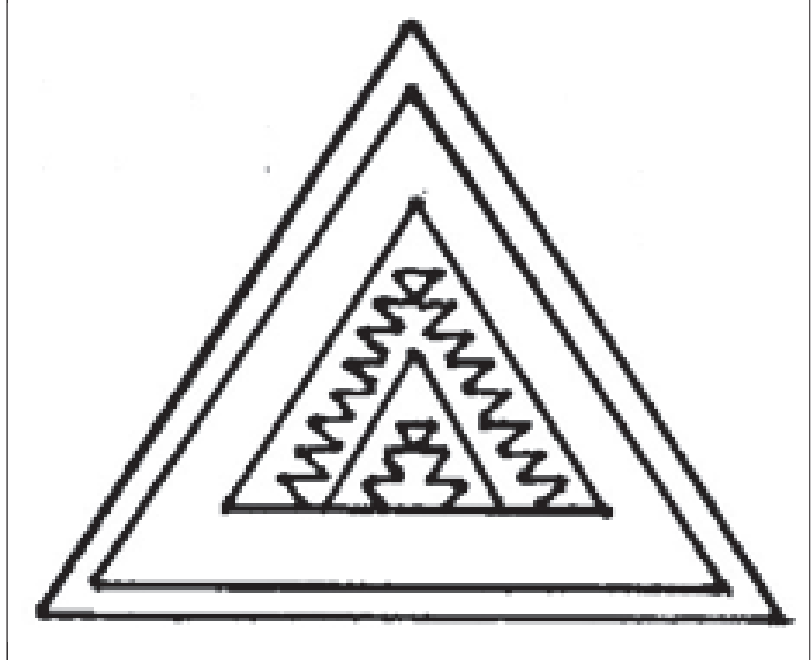

Çizim No : 13 Muska Motifi

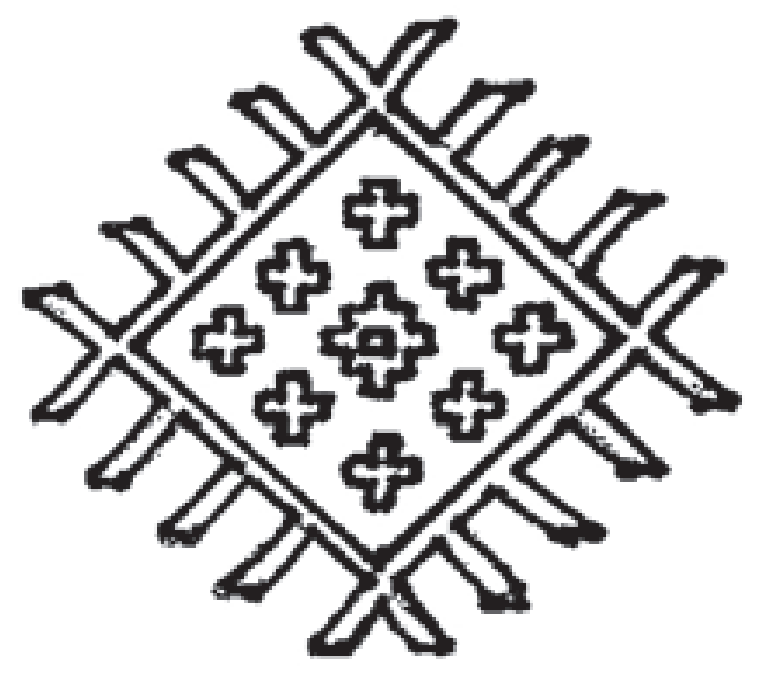

Çizim No : 19 Dulavratotu Motifi

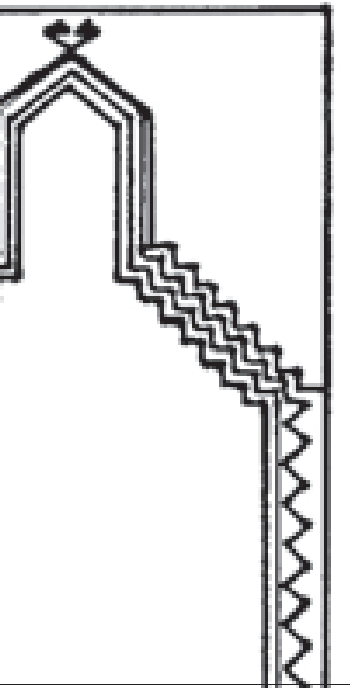


İsmail AYTAÇ

\section{Değerlendirme ve Sonuç}

Türk dünyasında, halı ve düz dokuma yaygılar öncelikle ihtiyacı karşılamak için dokunmuş olup, zamanla gelenek halini almıștır. Türklerde çadır veya evine yaydığı, kapısı eşiğine serdiği, süsleme yerleştirdiğgi, kapısının üzerine astığı veya gerdiği, çadıının kenarına yerleştirdiği, hayvanının sırtına örttüğü dokumalar günlük bir kullanım eşyasıdır. Yeni evlenecek insanlar için çeyiz hazırlamak, öldüğünde, sağlığında hazırladığı bir dokumayı, hayır amacıyla dini ve sosyal bir kuruma bağışlamak için, halı ve düz dokuma yaygı dokumak gelenektir. Anadolu'da, camiler bu gelenek sayesinde bir depo halini almış ve bu halı ve düz dokumalar günümüze kadar gelebilmiştir.

Anadolu'da, yakın zamanlara kadar her genç kız, halı ve düz dokuma bilmek zorundaydı. Bu gelenek, günümüzde belki şehirlerde ortadan kalkmıştır, ama köylerde hâlâ devam etmektedir

Bu çalışmamızda incelenen halılar, 1970-79 yılları arasında Elazığ Müzesince satın alınmışlardır. Halıların arka kısmında satın alma yılı ve envanter kayıt numaraları bulunmaktadır. Katalog bölümünde her halının, envanter numarası, müzeye geliș tarihi ve kimden satın alındığı belirtilmiştir

2003-2004 yıllarında incelenen halıların,19. ve 20. yüzyıllara ait oldukları belirlenmiştir. Bu halıların yapılış tarihi veya dokundukları dönemleri belirlemek için Türk Halı Sanatı'nın tarihi gelişimi dikkate alınarak kullanılan motif, renk ve kataloglardaki benzer örnekler incelenmiştir. Ayrıca bazı halıların dönemini tespit etmede emin olabilmek için kaynak kişilere başvurulmuştur. Eserlerin kesin tarihlendirmesini yapabilmek için kitabesinin bulunması önemlidir. Fakat incelenen halıların hiçbirinin kitabesi mevcut değildir.

Halıların yörelerinin tespitinde, yukarıda belirtildiği üzere yöresi kesin olan örnek çalışmalar incelenmiş, motif ve renkler araştırılarak belirlenmiştir. Ayrıca kaynak kişiler ve yayınlardaki bilgiler karşılaştırılarak karar verilmiştir. Bu bilgiler ışığında incelenen halıların, Elazı ̆ (Şavak), Sivas, Akdağı Madeni (Konya-Kırşehir), Kırşehir (Mucur), yörelerine ait oldukları bilinmektedir. Bu halılar, ticari yollarla ya da tarihçe başlı̆̆ında belirtildiği üzere belli yörelerin motiflerinin veya üslup özelliklerinin diğer birkaç bölgeyi etkilemesiyle de oluşmuş olabilir. Bu örnekler benzer motifler kullanılarak Elazı ğ yöresinde de dokunmuş olabilir. ${ }^{45}$ İncelenen halıların, yöre olarak dağılımı şöyledir: Elazı ̆ (Şavak) yöresine ait 1 adet

45 Halıların dönemi ve yöreleri hakkında geniş bilgi için bkz. Türk E Dokuması Halılar Katalogu, Cilt: 1,2,3,4,5. Kültür Bakanlığı Yayınlar1, Ankara, 1998; B. Deniz, a.g.e.; N. Görgünay, a.g.e.; M. M. Kutlu, Şavaklı Türkmenlerde Göçer Hayvancılık, Kültür ve Turizm Bakanlığı Ankara 1987

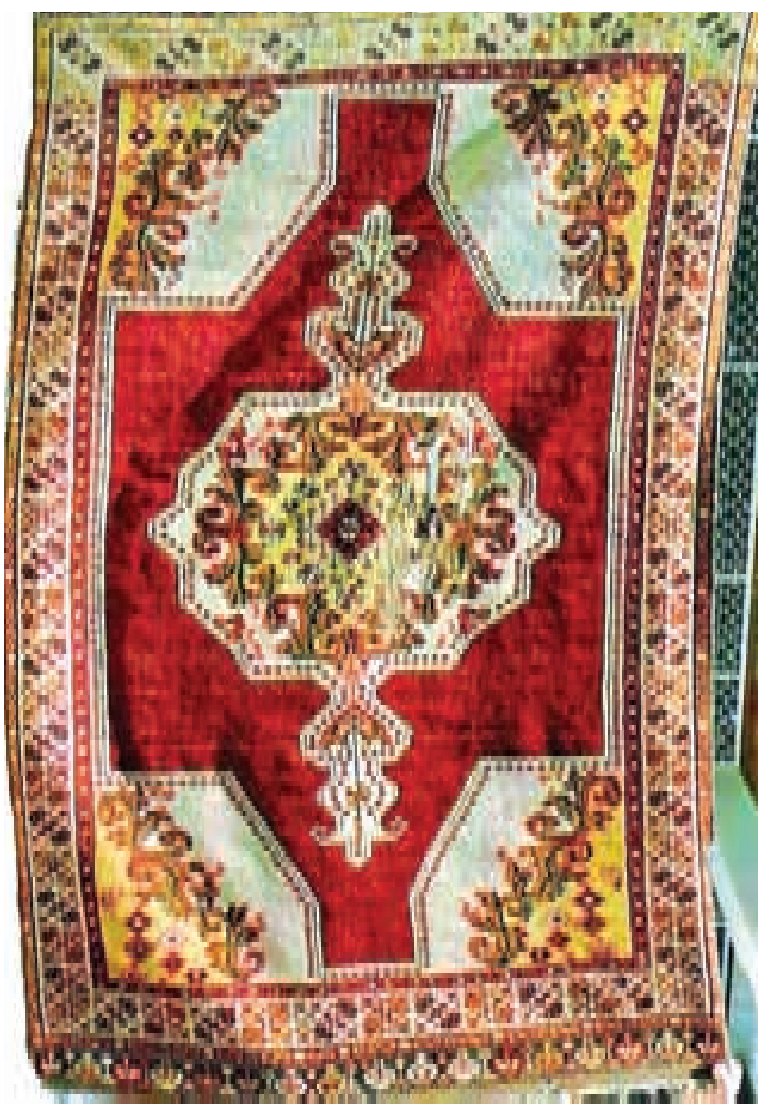

Örnek No : 1 Elazığ Müzesi, Envanter No:73/F.34-40 2003

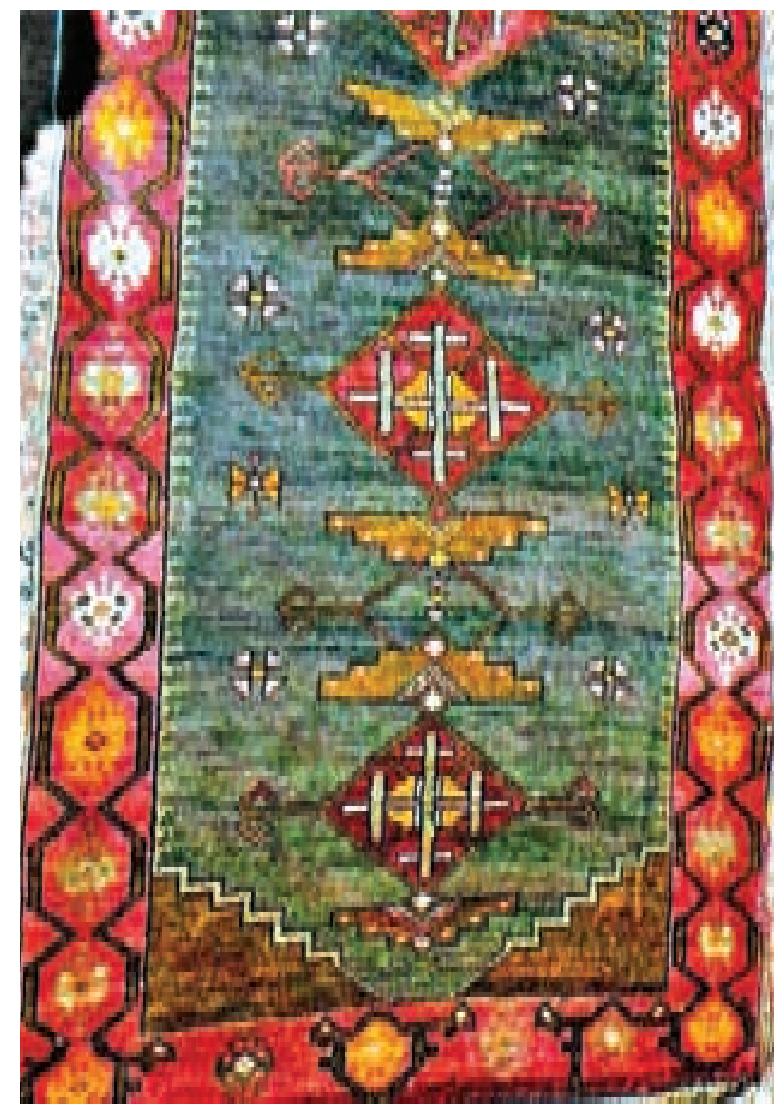

Örnek No : 2 Elazı ğ Müzesi, Envanter No:79/F.7-3 2003 


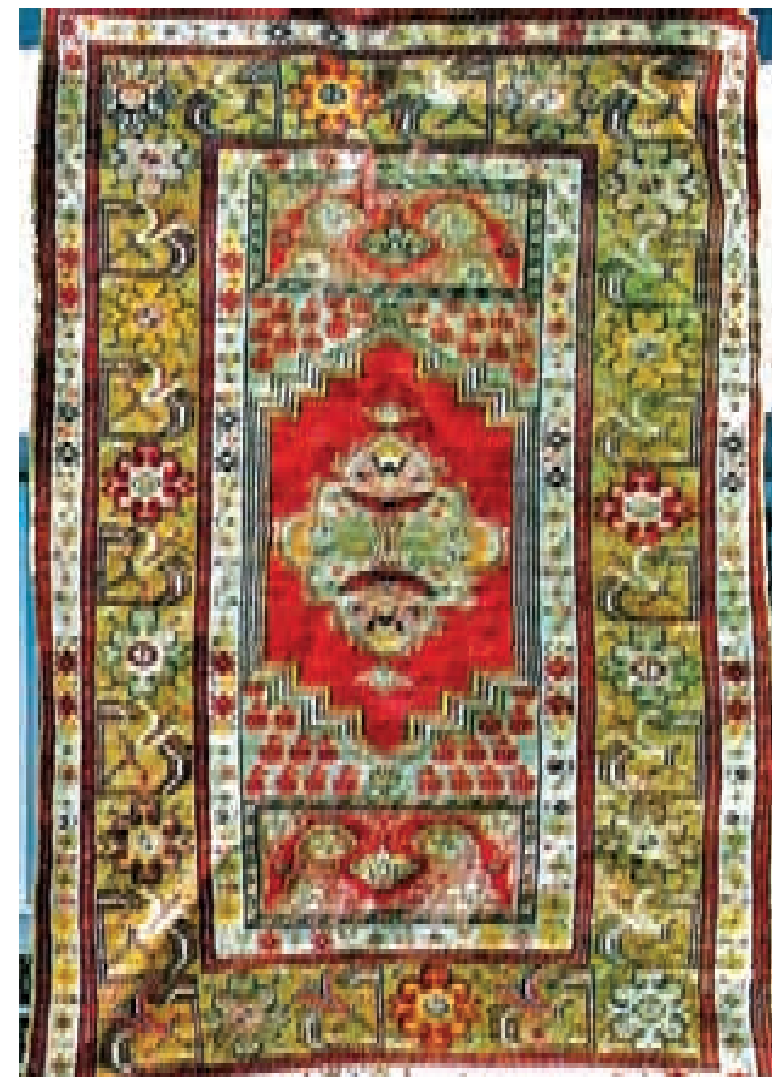

Örnek No : 3 Elazı̆̆ Müzesi, Envanter No:75/F.30-40 2003

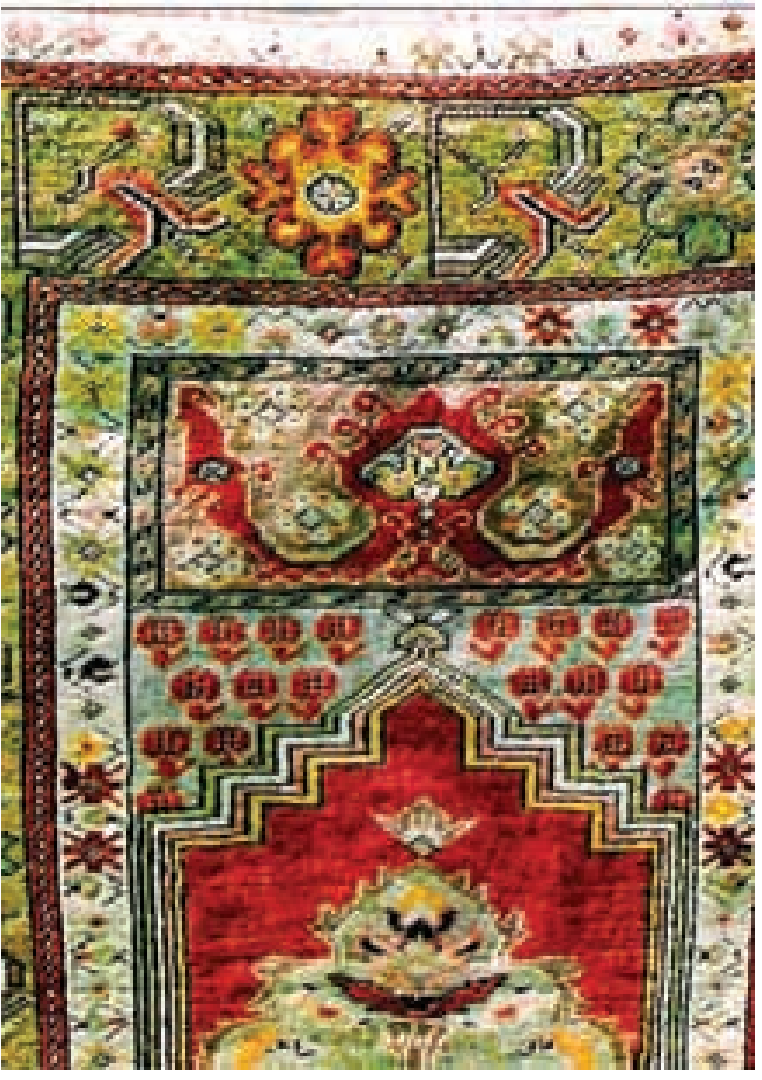

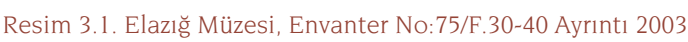

halı bulunmaktadır. (Eser No: 5). Sivas yöresine ait 2 adet halı bulunmaktadır. (Eser No: 2,4). Kırşehir (Mucur) yöresine ait 1 adet halı bulunmaktadır. (Eser No: 3). Konya-Kırşehir (Akda ̆̆ Madeni) yöresine ait 1 adet halı bulunmaktadır (Örnek No: 1).

Halıların bu günkü durumları, yerinde tespit edilip gözlem fişlerinde belirtilmiştir. Bazı halıların renklerinde, atkı, çözgü ve düğüm ipliklerinde kullanıma bağlı olarak aşınmalar meydana gelmiştir. Bazı örneklerin enine ve boyuna bordürlerinde motif eksiklikleri bulunmaktadır. Ayrıca halıların renklerinde de zamanla ağarmalar meydana gelmiştir.

Halıların, cinsinin ve sınıflandırılmasının yapılmasında kaynaklar incelenmiştir. Belirlenen halılar zemine düz bir şekilde gerilerek serilip şerit metre ile ölçüleri alınmıştır. Katalog kısmında her halının eni ve boyu santimetre cinsinden belirtilmiştir. Halıların sınıflandırılması ve boyutları şöyledir. İncelenen halıların içerisinde 3 adet eşik halısı bulunmaktadır (Örnek No: 1, 2, 3). Seccâde halısı $121 \times 148 \mathrm{~cm}$. ebatlarında üç mihraplı 1 halı bulunmaktadır (Örnek No:4). Müzede incelenen 1 namazlık halısı $73 \times 105 \mathrm{~cm}$ ebatlarındadır (Örnek No: 5).

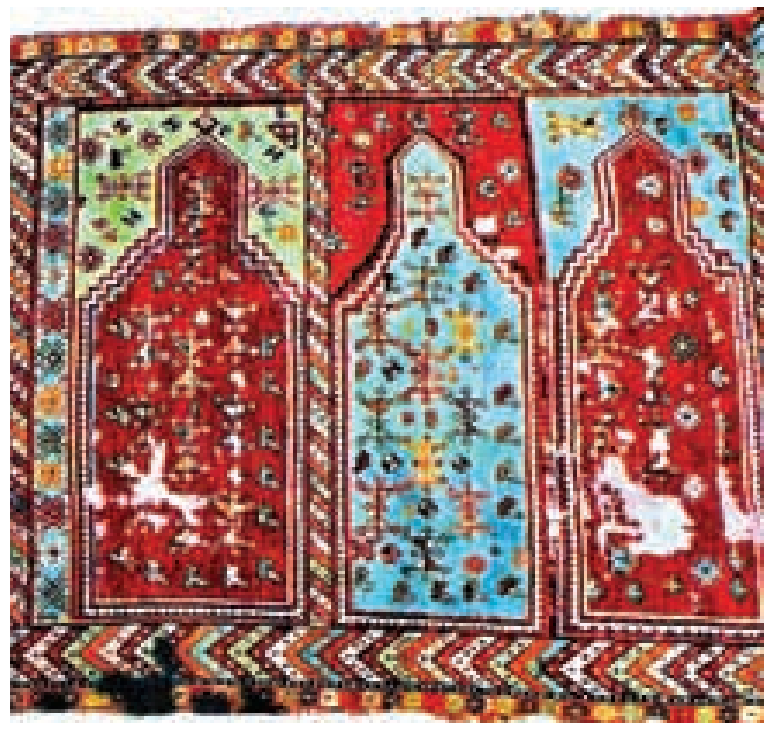

Örnek No : 4 Elazı̆̆ Müzesi, Envanter No:71/F.9-8 2003

Müzede incelenen halıların atkı, çözgü ve düğüm ipliklerinde genellikle yün malzeme kullanılmasına rağmen kısmen de pamuk da kullanılmıştır. Yün malzeme sağlık açısından ve sıcak tutma yönüyle önemli bir yer teşkil etmektedir

Halıda dört tür düğüm tekniği kullanılır. Bunlar, Türk düğümü (Gördes düğümü), İran düğümü (Sine düğümü), Hekim düğümü (Isparta düğümü) ve Tek 
İsmail AYTAÇ

çözgü üzerine düğümdür. İncelenen 5 adet halıda Türk (Gördes) düğüm tekniği kullanılmıştır. Bu halılarda kullanılan düğüm ipliği tekniği katalog kısmında belirtilmiştir (Örnek No: 1-5).

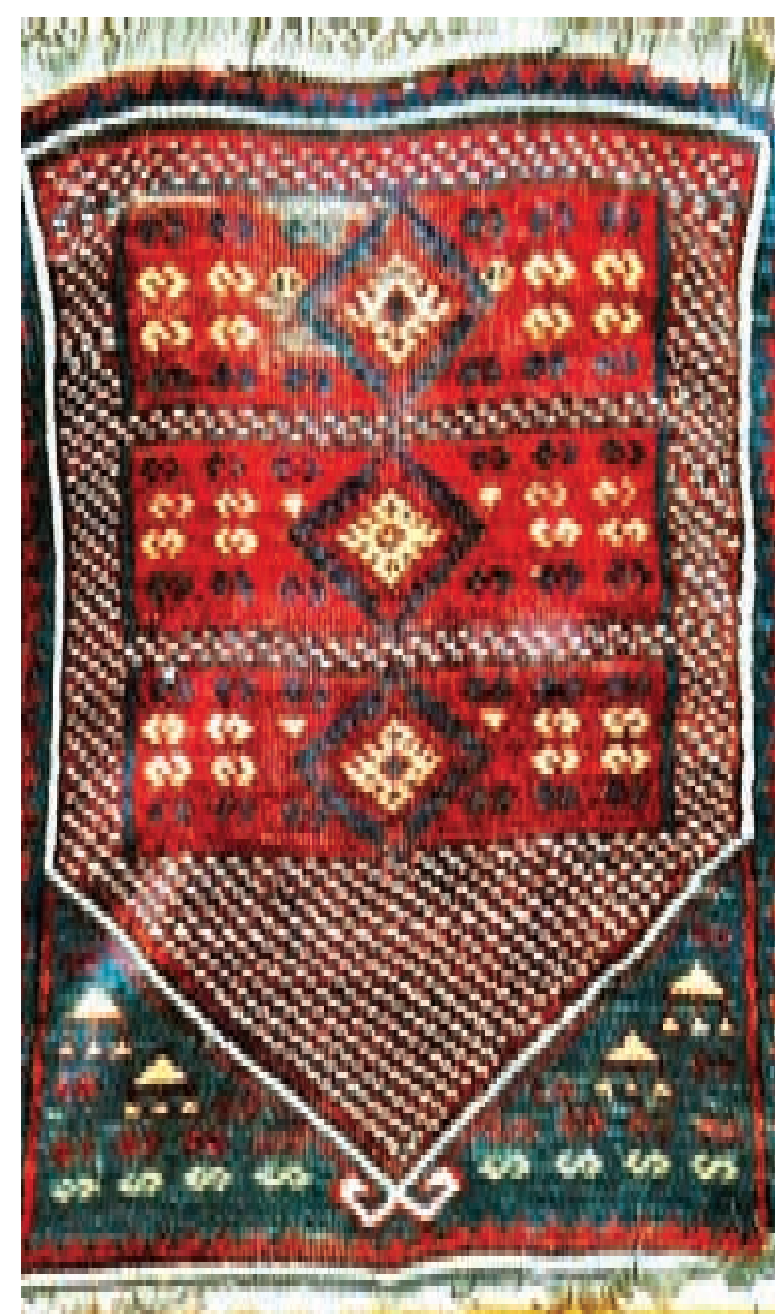

Örnek No : 5 Elazığ Müzesi, Envanter No:74/F.41-1 2003

$10 \mathrm{~mm}^{2}$ deki düğüm sayılarını bulmak için, incelenen her halı, tüylü tarafı alta gelmek üzere, gergin olarak düz bir yere yayıldıktan sonra, enine ve boyuna $10 \mathrm{~mm}$ 'lik uzunluklar belirlenerek, bu işaretler arasındaki düğümlür sayılır. İncelenen halıların erine ve boyuna düğüm iplikleri sayılarak 10 mm² düğüm sayıları katalog kısmında belirlenmiştir. Bu halılardaki dokuma yoğunluğu sırasıyla şöyledir: 115, 60, 103, 81, 67 gibi. Bu halıların az düğüm sayısı olanlara kaba halılar denilmektedir. Orta kalitede ve kaliteli halılarda düğüm sayısına göre mevcut olduğu tespit edilmiştir

Halılarda hav yüksekliği genellikle 0,5 - $1 \mathrm{~cm}$ arasında değişir. Yüksek havlı örnekler kalitesiz kabul edilir. Müzedeki örnek halıların hav yükseklikleri 0,3 - 1,5 cm arasında değişmektedir. Katalog kısmında her halının hav yüksekliği belirtilmiştir (Örnek No: 1 - 5).

Incelenen halılarda, ipliklerin boyanmasında doğal ve suni boyalar kullanılmıştır. Atkı ve çözgüler genellikle boyanmamıştır. Dügüum ipliklerinde ve kenar örgülerinde kırmızı, siyah, mavi, lacivert, beyaz, yeşil, turuncu, kahverengi, pembe, bordo ve turkuaz renkler kullanılmıştır (Örnek No: 1 - 5).

$\mathrm{Bu}$ araştırmada incelenen halıların desenlerinin özelliklerini ayrı ayrı belirtebilmek amacıyla, geometrik desenli halılar, bitkisel desenli halılar, mihraplı halılar, hayvan resimli ve manzaralı halılar olmak üzere dört grup halinde etüt edilmeleri uygun görülmüştür.

Anadolu halı ve düz dokumalarında zemin, kare, eşkenar dörtgen, sekizgen veya farklı geometrik şekillerden meydana gelen, küçük göbeklerle doldurulabilir. Halının merkezini belirten bu süslemelerin her biri içine, yeniden geometrik karakterli desenler işlenir. Halk arasında göl, göbek, madalyon, tabak veya farda denir.

Bitkisel desenli altıgen madalyonlu halılar 3 adet olup, zemin ve bordürlerinde stilize edilmiş bitki dalları, çiçekler ve gül motifleri yer almaktadır (Örnek No: 3).

Tek madalyonlu halı grubuna giren bir adet halı örneğinde, genellikle benekler, bitkisel motifler kullanılmıştır. Bitki dalları, yapraklar geometrik çiçekler, bitki filizleriyle süslenmiştir (Örnek No: 1).

Anadolu'da dokunan halılarda mihrap genellikle tek veya çift yönlüdür. Mihraplı halılar veya seccadeler grubuna girer. İki adet halı incelenmiştir. Bu halılar Sivas ve Elazığ yörelerine aittir. Sivas halısı üç kişilik saf seccâdesi olup zemininde yeşil, kırmızı, beyaz, mavi, siyah kontürlerle oluşturulmuştur. Halının zemininde göz, karanfil, akrep motifleri yer almaktadır. Halının bordürleri ise, bereket ve stilize çiçek motifleriyle süslenmiştir (Örnek No: 4). Elazığ yöresine ait olan mihraplı halı ise tek kişilik seccâdedir. Halının zemininde mavi ve kırmızı renkler kullanılmıştır. Mihrabın ucu koçboynuzu motifiyle süslenmiştir. Ayrıca zeminde dulavratotu, S (çengel), bereket, (sinekli), muska motifleri de bulunmaktadır. Bordür ve bıçkır motifiyle süslenmiştir (Örnek No:5). 
Anadolu'da halı ve düz dokuma desenine model, örnek, nakış gibi isimler verilir. Bu yüzden, her boyun, bunların yerleştiği her köyün, her dokuma merkezinin motifi farklıdır ve değişik anlamlar ifade eder ${ }^{46}$. Halılarda en çok geometrik karakterli motifler, bitki desenleri, eşya ve hayvan tasvirleri ile geleneklere bağlı motifler ve dini semboller kullanılır. Söz konusu motiflerin hepsi de halının her yerinde kullanılabilir.

Selçuklu halılarında görülen motifler, Beylikler ve Osmanlılar döneminde kullanılmış çok az değişiklik geçirerek günümüze kadar gelmiştir ${ }^{47}$. Sözgelimi, halı ve düz dokuma yaygılarda zeminin karelere veya eşkenar dörtgenlere ayrılması, Selçuklu halılarına Pazırık halısından gelen bir Orta Asya geleneği$\operatorname{dir}^{48}$. Aynı gelenek günümüze kadar gelmiştir.

İncelenen halıların zemin ve bordürlerinde stilize çiçek, gül motifleriyle, bitki dalları ve filizleri kullanılmıştır (Örnek No: 3, 4)

Halılarda en çok kullanılan motiflerden biri de hayat ağacı motifidir. Ağaç, Türkler arasında kutsal sayılan bitkilerdendir. Halıların zemini genellikle dal ve yaprakları bulunan bir ağaç motifiyle süslenir. Türk mitolojisinde Cenneti sembolize eden iki tavus kuşu tarafından korunurken tasvir edilir Hayat ağacı motifi genellikle aslan, tavus kuşu, ejder çiftleri tarafından korunurken tasvir edilmektedir. Hayat ağacı motifi, ölümsüzlüğü ve ruhun sonsuzluğun simgelemektedir. Bu motif Anadolu halılarında dönemlerdeki geleneğe bağlı olarak

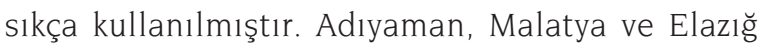
halılarında bu motifler mevcuttur (Örnek No: 1).

Anadolu'da, ejder, ejderha, şahmerân motifi bazen, halk arasında, yılanın büyük şekli olarak da düşünülür. Hayat ağacını koruma amaçlı tasvir edilmektedir (Örnek No: 1,3).

Anadolu'da dokunan halılarda mihrap genellikle tek veya çift yönlüdür. Mihrap şekli ne olursa olsun, mihrabın etrafı dikdörtgen bir çerçeveyle kuşatılır ve genellikle mihrabın direği diye isimlendirilir. Camilerdeki mihrabın halılara motif olarak yansımasıdır. Özellikle namazlık veya seccâde türü

46 Halılarda kullanılan motifler için bkz. B. Deniz, a.g.e., s. 177-201; N. Görgünay, a.g.e., s. 37-133.; N. Görgünay, Oğuz Damgaları ve Göktürk Harflerinin El Sanatlarımızdaki İleri, Ankara, 2002,s. 1-108.

47 Osmanlı dönemi motifleri için bkz. B. Deniz, "Osmanlı Dönemi Halı ve Düz Dokuma ve Yaygıları", Türkler Ansiklopedisi, C. 12, Ankara, 2002, s.385-400

48 E. F. Tekçe, Pazırık, Altaylardan Bir Halının Öyküsü, Ankara, 1993. dokumalarda kullanılan mihrabın bulunduğu alanı kuşatan çerçeve arasındaki bölüme koltuk köşe denir (Örnek No: 2,5).

$\mathrm{S}$ (Çengel) motifi de nazara karşı kullanılan motiflerdendir. Çengelli baklava (akrep) motifi, dokuyan kişiyi ve ev halkını kötülüklere ve nazara karşı korumak amaçlıdır. Genellikle halıların zemin ve madalyonların tam orta kısmında yer alır. Çengel (S) motifi zeminde ve bordürlerde üç sıra halinde yer alır. Bu motifin sıkça kullanıldığı halılar çalışmamızda mevcuttur (Örnek No: 5).

Nazar ile ilgili motiflerde göz'de bir motif olarak karşımıza çıkar. Halk arasında, göz değmek, nazara gelmek şeklinde ifade edilen nazar ve uğur olarak kullanılır. Halk inanışına göre, bazı insanlar bakışlarıyla karşısındakini etkiler veya etkisiz hâle getirebilir. Bu nedenle halı ve düz dokumalara, daha dokumaya geçmeden evvel ve dokuma bittiksen sonra, dokumanın kilimlik kısmına göz ve nazara iyi gelen göz motifi işlenir. Böylece dokumaya ve dokucuya göz değmesi önlenir (Örnek No:1).

Anadolu halılarında en sık karşılaşılan motiflerden biri de, yine güç, kuvvet ve tılsımına inanılan muska veya hemaîl isimleriyle anılan motifler$\operatorname{dir}^{49}$. Çoğu kez üçgen şeklinde işlenen bu motifin, tüm Anadolu'da taşıyan kişiyi kötülük, uğursuzluk ve nazardan koruduğuna, güç, kuvvet ve cesaret verdiğine inanılır. Bu nedenle halı ve dokumalarda da işlenir (Örnek No: 5).

Bordürlerde kullanılan kenar suyu akarsu motifleri saflığı ve temizliği ifade etmektedir. Araştırmamızdaki halıların bordürlerinde bu motifler kullanılmıştır (Örnek No: 1-5)

Ayrıca halılarda mevcut olan sandık, tarak, saç bağı, dulavratotu motifleri dokuyan genç kızın hayallerini süsleyen evlenmeyi ve duvak temsil etmektedir. Dokunan halıların çoğu çeyiz amaçlı olduğu için bu tür motifler sıkça karşımıza çıkmaktadır (Örnek No: 1-5). Başak, bereket motifleri ise bolluğu ve dolu dolu bir hayatı simgelemektedir (Örnek No: 3,4, 5, ).

Halıların renkleri, motifleri, hav yükseklikleri, düğüm sayısı, boyutları tablo halinde ekler kısmında ayrica sunulmuştur.

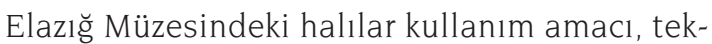
nik, motif ve renk bakımından genel Türk halı sanatı kapsamında değerlendirilmelidir.

49 B. Deniz, a.g.e., s. 75 
İsmail AYTAÇ

\section{Kaynaklar}

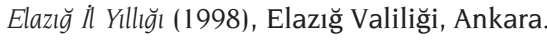

Acun Hakkı (1998), "Türk Halı Sanatındaki Yozlaşma”, Türk Soylu Halklarının Halı, Kilim ve Cicim Sanatı Uluslararası Bilgi Şöleni Bildirileri, Kayseri, 1996, s. 15-23, Ankara, AKM Yayını.

Anonim, (1998), Türk El Dokuması Halılar, C. 1, 2, 3, 4, 5, Ankara, Kültür Bakanlığı Yayınları

Ardiçoğlu Nurettin (1964), Harput Tarihi, İstanbul.

Arslan Celil (2003), Elazığ'da Türk İlam Dönemi Yapıları, Selçuk Üniversitesi Sosyal Bilimler Ens. (Yayımlanmamış Doktora Tezi), Konya.

Aslanapa Oktay (1987), Türk Halı Sanatının Bin Yll, İstanbul, Eren Yayıncılık

Aşan M. Beşir (1992), Elazığ, Tunceli ve Bingöl İllerinde Türkistan İleri, (XII-XIII. Yüzyıllar), Ankara.

Ataoğlu Remzi (1992), “Harput'ta Artuklu İdaresi”, Tarih İçinde Harput, s.53-57, Elazı ̆̆. F.Ü. Araştırma Merkezi Yayınları.

Artuk İbrahim (1944), Mardin Artukoğulları Tarihi, İstanbul.

Aytaç Gülsüm (2004), “Elazığ Arkeoloji ve Etnoğrafya Müzesi”, Harvak, Y.1, S.2, s. 72-74, Elazığ.

Aytaç İsmail, vd. (1992), Malatya Motifi Yöresel El Sanatlarımız, Ankara.

Danık Ertuğrul (1999), “Ortaçă̆ Harput'unun Kentsel Gelişimi”, Dün ve Bugünüyle Harput Sempozyumu, C.1, s. 17-49, Ankara.

Darkot Besim, (1950), "Harput", İlam Ansiklopedisi, MEB Yayınları, C. 5, s. 296-299.

Deniz Bekir (2000), Türk Dünyasında Halı ve Düz Dokuma Yaygıları, Ankara: AKM Yayınları

, (2002), "Osmanlı Dönemi Halı ve Düz Dokuma ve Yaygıları.", Türkler Ansiklopedisi, C. 12, s.385-400, Ankara. Yeni Türkiye Yayınları.

,(2009), "Türk Dünyasında Ölümlük Halı, Düz Dokuma Yaygı ve Keçe Geleneği.", Akdeniz Sanat Dergisi, s.1-16, Antalya.

Durul Yusuf (1987), Türk Kilim Motifleri, Ankara.

Evliya Çelebi (1986), Seyahatname, C.3-4, İstanbul.

Genç Reşat (1998), “Kaşgarlı Mahmud'a Göre XI. Yüzyılda Türklerde Dokuma ve Yaygı İşleri", Türk Soylu Halklarının Halı, Kilim ve Cicim Sanatı Uluslararası Bilgi Şöleni Bildirileri, s.131-135, Ankara, AKM Yayınları.

Görgünay Neriman (1977), Doğu Yöresi Halıları, Ankara, Türkiye İş Bankası Kültür Yayınları

-......., (2002), Oğuz Damgaları ve Göktürk Harflerinin El Sanatlarındaki iżleri, Ankara. Kültür Bakanlığı Yayınları.

Hallaçoğlu Ahmet,(1994)“Elazı̆̆ Maddesi”, İlam Ansiklopedisi, C. 10,s.551,552, İstanbul, TDV Yayınları.

Honigman Ernst (1970), Bizans Devletinin Doğu Sinırı, ( Tercüme: Fikret Işıltan), İstanbul.

Kafalılar A (1982), Halııılı Teknolojisi, Ankara: T.C. Köy İşleri ve Kooperatifleri Bakanlığı Kooperatifler Genel Müdürlüğü.
Karamağaralı Beyhan (1997), "Türk Halı Sanatındaki Motiflerin Yorumu Üzerine”, Arıs, Y.1, S.3, s. 28-39, Ankara, AKM. Yayınları

Kırzıoğlu M. Fahrettin (1963), "450 Yıl Önceki Harput Mahalleleri ile Nahiyeleri", Yeni Firat, S. 17,s.1718 ,ístanbul.

Kırzıoğlu Neriman Görgünay (1995), Altaylardan Tuna Boyuna Türk Dünyası'nda Ortak Motifler, Ankara, Kültür Bakanlığı Yayınları.

Kutlu M. Muhtar (1987), Şavaklı Türkmenlerde Göşer Hayvancillk, Ankara, Kültür Bakanlığı Yayınları.

Memişoğlu Ferhan (2006), Harput'da Gelenekler, Inançlar ve El Sanatı, Ankara.

Sunguroğlu İshak (1958), Harput Yollarında, C. 1, İstanbul.

Sümer Faruk (1984), Karakoyunlular, Ankara, TTK Yayınları.

Tekçe E. Fuat (1993), Pazırık, Altaylardan Bir Halının Öyküsü, Ankara, Kültür Bakanlığı Yayınları.

Tuncel Mehmet (1994), “Elazı̆̆ “, İslam Ansiklopedisi, C.10, s. 553, İstanbul: TDV Yayınları.

Turan Osman (1993), Selçuklular Zamanında Türkiye, İstanbul, Boğaziçi Yayınları.

Tüten Ahmet (2004), Elazığ Müzesindeki Halılar, F.Ü. Sosyal Bilimler Enstitüsü, Yayınlanmamış Yüksek Lisans

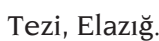

, (2004), "Şafak Yastık Halıları", Şafak Bülteni, S.20, s. 11-15, Elazı̆̆.

Yinanç M. Halil (1994), Türkiye Tarihi, Selçuklular Devri, İstanbul. 


\section{EKLER}

\section{TABLOLAR}

Tablo 1: Halıların boyutları, düğüm tekniği, hav yüksekliği ve düğüm sayısı

\begin{tabular}{|c|c|c|c|c|}
\hline $\begin{array}{c}\text { Katalog } \\
\text { No }\end{array}$ & $\begin{array}{c}\text { Boyutları } \\
\text { En x Boy }(\mathrm{cm})\end{array}$ & Düğüm Türü & Hav yüksekliği (mm) & Düğüm Say1S1 $\left(10 \mathrm{~mm}^{2}\right)$ \\
\hline 1 & $104 \times 170$ & Türk (Gördes) & 5 & 60 \\
\hline 2 & $101 \times 261$ & Türk (Gördes) & 6 & 115 \\
\hline 3 & $107 \times 165$ & Türk (Gördes) & 3 & 81 \\
\hline 4 & $121 \times 148$ & Türk (Gördes) & 10 & 67 \\
\hline 5 & $73 \times 105$ & Türk (Gördes) & 6 & 6 \\
\hline
\end{tabular}

Tablo 2: Halıların sınıflandırılması ve kullanılan motiflerin dağılımı

\begin{tabular}{|c|c|c|c|c|c|c|c|c|c|c|c|c|c|c|c|c|c|c|c|c|c|c|}
\hline $\begin{array}{l}0 \\
Z \\
0 \\
0 \\
\frac{0}{\pi} \\
\text { U } \\
V\end{array}$ & 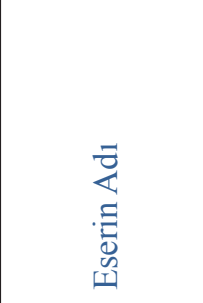 & 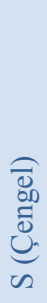 & :O & 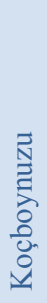 & 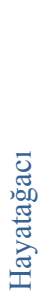 & 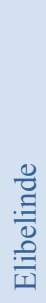 & 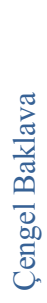 & $\frac{N}{\bar{J}}$ & $\frac{\Xi}{\bar{\Xi}}$ & 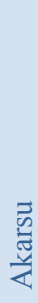 & 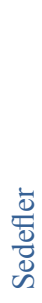 & 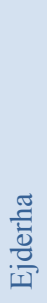 & 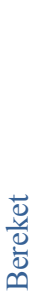 & 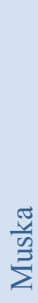 & 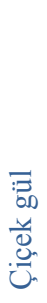 & 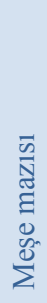 & 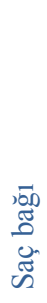 & 己. & 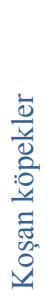 & 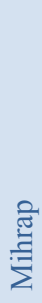 & 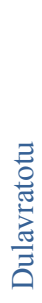 & 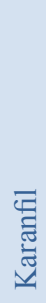 \\
\hline 1 & Eşik halısı & $\mathrm{X}$ & $\mathrm{X}$ & & $\mathrm{X}$ & & & $\mathrm{X}$ & & & & & & & $\mathrm{X}$ & & & & & & & \\
\hline 2 & Eşik halısı & & & $X$ & & & $\mathrm{X}$ & & & $X$ & & & & & $\mathrm{X}$ & & $\mathrm{X}$ & & $X$ & & & \\
\hline 3 & Eşik halısı & & & & $\mathrm{X}$ & & & & & $X$ & & X & & & $\mathrm{X}$ & & & $\mathrm{X}$ & & & & \\
\hline 4 & Seccade halısı & & $X$ & & & $X$ & $\mathrm{X}$ & & & & $\mathrm{X}$ & & $X$ & & & $\mathrm{X}$ & & & & $\mathrm{X}$ & & $X$ \\
\hline 5 & Namaz halısı & $\mathrm{X}$ & & X & & & & & $\mathrm{X}$ & & $X$ & & $X$ & X & & & & & & $\mathrm{X}$ & $\mathrm{X}$ & \\
\hline
\end{tabular}

Tablo 3. Halıların Yöreleri ve Kronolojik Dağılımı

\begin{tabular}{|l|l|l|}
\hline K.No & Yöreleri & Kronolojik Dağılımı (y.y.) \\
\hline 1 & Akdağ, Madeni (Konya-Kırşehir) & 19. Yüzyılın ikinci yarısı \\
\hline 2 & Sivas & 20. Yüzyılın ortaları \\
\hline 3 & Kirşehir (Mucur) & 19. Yüzyılın başları \\
\hline 4 & Sivas & 19. Yüzyılın ilk yarısı \\
\hline 5 & Elazı̆ & 19. Yüzyılın ortaları \\
\hline
\end{tabular}

